CENTRO UNIVERSITÁRIO DE BRASÍLIA - UnICEUB

FAJS - FACULDADE DE CIÊNCIAS JURÍDICAS E SOCIAIS

\author{
PROGRAMA DE INICIAÇÃO CIENTÍFICA
}

VICTOR YUDI ICHIHARA SADO

O QUE HÁ DE RACIONAL NA RAZÃO DO DIREITO? UMA ANÁLISE DA DOGMÁTICA JURÍDICA E SEU REFLEXO NA DECISÃO JUDICIAL

BRASÍLIA 
CENTRO UNIVERSITÁRIO DE BRASÍLIA - UniCEUB

\author{
VICTOR YUDI ICHIHARA SADO
}

\title{
O QUE HÁ DE RACIONAL NA RAZÃO DO DIREITO? UMA ANÁLISE DA DOGMÁTICA JURÍDICA E SEU REFLEXO NA DECISÃO JUDICIAL
}

Relatório final de pesquisa de Iniciação Científica apresentado à Assessoria de Pós-Graduação e Pesquisa pela Faculdade de Ciências Jurídicas e Sociais.

Orientação: Professora Dra. Alessia Barroso Lima Brito Campos Chevitarese

BRASÍLIA 
Para minha família. 


\section{Agradecimentos}

Gostaria de agradecer à minha orientadora, Alessia Chevitarese, por ter acolhido tão simpaticamente um aluno ainda novo nos estudos de Direito que, no entanto, tomava, ingenuamente, iniciativas de investigação num campo tão conturbado na Filosofia do Direito. Período este em que foi feito a pesquisa, pelas longas conversas e leitura de livros pela qual foi me aconselhado, serviu não só para o meu amadurecimento intelectual, mas também como crescimento como pessoa. Queria agradecer ainda a professora pelo fato de ter concedido tamanha liberdade para mim na pesquisa que, pacientemente, me orientava sem desinibir o interesse e as inquietações que ensejaram em mim ao longo da investigação.

Queria agradecer também a UniCEUB que ajudou por meio de minicursos e palestras esta pesquisa e também pela bolsa oferecida pela instituição.

Por último, queria agradecer a minha família que sustenta meus objetivos no âmbito acadêmico. Motivo pela qual o ofício de pesquisa se torna ainda mais interessante. 
"O ideal está fixado em nossos olhos de forma irremovível. Você pode sair dele. Você tem que voltar sempre de novo. Não existe um fora: lá fora falta 0 ar vital - Donde vem isto? A ideia está colocada por assim dizer, como óculos sobre o nosso nariz, e o que vemos, vemo-lo através dele. Não nos ocorre retira-los." (Ludwig Wittgenstein). 


\section{O QUE HÁ DE RACIONAL NA RAZÃO DO DIREITO? UMA ANÁLISE DA DOGMÁTICA JURÍDICA E SEU REFLEXO NA DECISÃO JUDICIAL}

Nome do aluno - UniCEUB, PIC Institucional, VICTOR YUDI ICHIHARA SADO Victorsado@gmail.com

Nome do professor orientador - UniCEUB, professora orientadora Dra. ALESSIA BARROSO LIMA BRITO CAMPOS CHEVITARESE

Alessia.chevitarese@uniceub.br

Colaboradores: Centro Educacional Leonardo da Vinci, colaborador (PIC Júnior), RODRIGO SANTOS NOGUEIRA JUNIOR

ro_santos66@hotmail.com

O pensamento racional é uma forma de interpretar o mundo. O homem desenvolveuo e forneceu-Ihe amplitudes diversas que se estendem em distintas perspectivas do conhecimento jurídico e social. No âmbito da dogmática jurídica, a preocupação central é a valorização dos aspectos lógico-formais das regras de aplicação do Direito positivo. Contudo, o Direito na contemporaneidade imerso em uma sociedade complexa e plural demanda uma interpretação mais ampla da realidade. Com efeito, vários fatores influenciam no processo de decisão, como por exemplo, acepções de ordem moral, religiosas, ideológicas, partidárias, dentre outras. A objetividade normativa passa a conviver com a indeterminação de certos conceitos de ordem valorativa. Nesse sentido, um dos grandes desafios da comunidade jurídica é tentar equacionar a segurança proporcionada pela dogmática jurídica com os critérios de incerteza e indeterminação enquanto elementos valorativos em um dado contexto social. Diante desse cenário, o problema central da pesquisa é analisar a racionalidade jurídica em sua razão prática. Isto é, como autoridades judiciais sob uma forma argumentativa sustentam uma crença no Direito racional. No que concerne à metodologia, a presente pesquisa possui a natureza explicativa no sentido de que objetiva propor reflexões necessárias ao campo do Direito através de uma discussão de ordem teórica.

Palavras-chave: Racionalidade, dogmática jurídica, decisão judicial, STF. 


\section{Sumário}

1 Introdução

$\begin{array}{lll}1.1 & \text { O problema da pesquisa } & 7\end{array}$

$\begin{array}{lll}1.2 & \text { A justificativa da pesquisa } & 8\end{array}$

$\begin{array}{lll}1.3 & \text { Objetivo da pesquisa } & 9\end{array}$

1.4 Metodologia da pesquisa 9

2 Revisão Bibliográfica 11

$2.1 \quad$ Formação da racionalidade jurídica 11

2.2 Normativismo versus Decisionismo: Constitucionalismo ou vontade do soberano. 21

2.3 Teoria Pura do Direito: o caráter anti-ideológico do pensamento kelseniano 24

2.4 Ontologia do Direito: insuficiência da racionalidade jurídica? 31

2.5 Legitimidade de uma decisão judicial: racionalidade procedimental $\begin{array}{ll}\text { institucionalizada juridicamente } & 38\end{array}$

2.6 Racionalidade jurídica no campo do agir decisional: uma análise dos votos do $\begin{array}{ll}\text { Supremo Tribunal Federal } & 41\end{array}$

2.6.1 Primeiro caso: Mandado de Segurança n ${ }^{\circ}$ 20. 257 - Distrito Federal 42

2.6.2 Segundo caso: Ação Direta de Inconstitucionalidade n ${ }^{\circ} 3510$ - Distrito Federal 44

2.6.3 Terceiro caso Ação Direta de Inconstitucionalidade (ADI) 4277 e a Arguição de Descumprimento de Preceito Fundamental (ADPF) 132 - Rio de Janeiro. 45

$\begin{array}{ll}\text { Conclusão } & 47\end{array}$

$\begin{array}{ll}\text { Referências } & 48\end{array}$ 


\section{Introdução}

O Direito é uma forma de expressão do conhecimento que se manifesta em teoria como fundamentação e na prática como um valor instrumental. Dado essa característica, a ordem jurídica é sujeita a ambivalências das quais são evidentes através da aplicação da racionalidade jurídica ao fundamentar um argumento coerente para resolver os problemas da realidade. Dualidade inerente que se manifesta justapostas ou antagônicas. A presente pesquisa tem por objetivo tratar dessa ambivalência, isto é, dos conflitos entre paradigmas de pensamento jurídico e sua expressão na realidade. Em função disso, há, no trabalho, claramente, um aspecto historicista para identificar os tipos de racionalidade jurídica.

Ao delinear a construção racional do Direito, observa-se a leveza na sua estrutura, ou seja, sua inconsistência, sobretudo, no que diz respeito o atrito entre a juridicidade e a política. Referido tipo de conflito também é de importância para pesquisa, pois ora questões racionais de ordem jurídica intervém no âmbito político; ora se abstém em aplicar o Direito, à sua pura literalidade, posto na lei.

No transcurso da pesquisa, tornou-se perceptível que a discordância que surge na práxis ocorre em detrimento do que entende-se por Direito, isto é, ao que propriamente é a sua natureza. Nesse sentido, a coerência de um pensamento, bem como sua fundamentação teórica vai corresponder às variações do tempo e às percepções de cada autor. E o sua racionalidade jurídica, confluente as exigências política da época.

Por fim, coube como objetivo final da pesquisa, avaliar como tais expressões da racionalidade jurídica são manifestas no Supremo Tribunal Federal. Para tanto, investigou-se os argumentos nos votos dos ministros para servir como dados empíricos à tipologia racional que o Brasil presenciou nas últimas décadas. Tal feito evidencia, a partir da prática, a racionalidade jurídica brasileira e transparece o que se entende por Direito.

\subsection{O problema da pesquisa}

O problema central da pesquisa é: como um estado latente da racionalidade jurídica satisfaz uma forma de justificação de argumento para implementação de uma lei e como, por conseguinte, cria, variável ao espaço e tempo, uma razão do 
Direito? Razão que coloca-se aqui se refere em como o Direito deveria ser pensado e aplicado. Portanto, evoca-se, nesta pesquisa, um debate sobre a natureza do Direito. Razão pela qual percebe-se que ela é o epicentro da discordância tanto teórica quanto prática do Direito.

Se a racionalidade jurídica que corporifica o Direito é a fonte primordial de sua própria sustentação, sua crise corresponde a uma crise do Direito. Por isso, a função do judiciário deve se manter, a medida do possível, clara e definível para assim estabelecer segurança jurídica. Contudo, não se pode perder de vista a ausência de representação eletiva no Poder Judiciário, e em certa medida como em sede de controle de constitucionalidade sua decisão apresenta um caráter contramajoritária, o que implica em repensarmos a legitimidade do Direito. Assim, seria responsável uma aplicação jurídica isenta de mediação popular, atenta, unicamente, a um rigoroso procedimento jurídico? Ou poderíamos repensar a racionalidade através de um diálogo entre o judiciário e o povo? Questões como essas recaem sobre a interface entre o Direito e a política, e devido uma insatisfação do povo às leis principalmente nas execuções de ofício em decisões judiciais, tais problemas são de grande relevância para a atualidade.

Conscientes de toda essa complexidade, o problema central da pesquisa, em última instância, é analisar a racionalidade jurídica em sua razão prática. Isto é, como autoridades judiciais sob uma forma argumentativa sustentam uma crença no Direito racional e transparecem um ideário do Judiciário.

Definir um conceito acerca da racionalidade pode se tornar um trabalho sem fim caso não se circunscreva, especificamente, o objeto de análise. Esta pesquisa, ciente desse vasto campo de conhecimento e da fácil suscetibilidade em cair na falha de delimitação do tema, procura avaliar, como intuito primeiro, a concepção que a racionalidade adquiriu a partir da Modernidade. Concluindo essa etapa, temse, sobretudo, como finalidade principal delinear as acepções do pensamento jurídico que legitimam a decisão judicial, bem como verificar as aplicações da doutrina enquanto fonte de Direito.

\subsection{A justificativa da pesquisa}

A presente pesquisa justifica-se porque se observa que a crise do Direito diante da complexidade social é mais precisamente uma crise nas decisões judiciais. 
As fundamentações teóricas cada vez mais anacrônicas, em função do desenvolvimento dos novos cenários sociais parecem insuficientes hoje. Assim, cabe ao homem do seu tempo se apropriar do que foi construído intelectualmente para ressignificá-lo ao seu período histórico. Nesse sentido, cabe repensar o juspositivismo em função das exigências da nossa realidade. Precisa como Roberto Gomes afirma "estar e depois ser". ${ }^{1}$ É necessário analisar a nossa situação histórica, os problemas que são evidentes em função do movimento, da mudança e das oscilações sociais e econômicas para tratar de um diagnóstico preciso e adequado para o momento.

Neste sentido, pesquisa busca esclarecer as possíveis nuances do Direito a partir de uma lógica historicista e também por uma investigação de argumento dos ministros do Supremo Tribunal Federal. É evidente, no entanto, pela escala da problemática, uma ausência de resposta definitiva. Assim como o homem, o Direito reserva uma organicidade, o que o torna mutável, dinâmico e complexo. Destarte, a importância dessa pesquisa está no compromisso de delinear (na história) a racionalidade jurídica e tentar identificar possíveis alternativas para repensarmos a racionalidade jurídica contemporânea.

\subsection{Objetivo da pesquisa}

O objetivo geral da pesquisa é avaliar como a racionalidade jurídica se manifesta atualmente no contexto do agir decisional nas decisões do STF. Pormenorizadas essas questões, podemos enxergar o propósito da pesquisa na sua integralidade. Sua especificidade diz respeito em a) Discutir temas como teorias do Direito, tal qual fundamentam uma natureza do jurídica; b) Investigar as teorias críticas que repercutem no agir decisional; c) Analisar a argumentação jurídica diante de uma crise do Direito do Juspositivismo.

\subsection{Metodologia da pesquisa}

No que concerne à metodologia, a presente pesquisa possui a natureza explicativa no sentido de que objetiva propor reflexões necessárias ao campo do Direito através de uma discussão de ordem teórica. Assim, procurou-se investigar e sistematizar os segmentos que colaboraram para a dogmatização da racionalidade e

\footnotetext{
${ }^{1}$ GOMES, Roberto. Crítica da razão Tupiniquim. São Paulo: FTD, 1990.
} 
suas consequências jurídicas na contemporaneidade. Quanto ao procedimento técnico restou realizado um levantamento bibliográfico dos principais autores das correntes de pensamento elencadas: Jusnaturalismo, Juspositivismo e doutrinas/teorias críticas na contemporaneidade.

Com efeito, apesar da pesquisa ter um fundo de preocupação empírica com o motivo de não se perder em abstrações bibliográficas, o estudo realizado aqui é em sua grande parte conceitual. Por isso, é necessário deixar claro que vários conceitos que vamos analisar ao longo da pesquisa que são essenciais para o entendimento do tema são razões práticas. Pode-se falar, nesse sentido, que buscamos uma espécie de epistemologia da qual vai desembocar na esfera políticojurídica. O conceito, nessas instâncias, serve como uma ponte do intelecto para a ação. O meio pela qual pode-se fazer do conhecimento um componente para mudar a realidade e diminuir, o máximo possível, a distância entre a teoria e a prática.

Para alcançar tais objetivos, considera-se importante também uma performance pedagógica. Isso significa, em outras palavras, em levar a prática além da atividade solitária de aprendizado junto com os livros. Ou seja, não só fazer uma separação do sujeito de pesquisa com o objeto de análise, mas tentar buscar uma apreensão do conhecimento a partir do diálogo. Isso se torna possível com a conversa que se desenvolve entre o orientador e orientado. Evidente, na troca de ideias, de erros, de incongruências. Nessas instâncias, percebe-se um ambiente propício para novos pensamentos. Logo, há uma ênfase na questão intersubjetiva para o desenvolvimento da pesquisa.

Além disso, a fim de se compreender e expor melhor o tema procurou-se seguir uma linearidade cronológica da teorias, de forma a ensejar, naturalmente, os respectivos problemas político-jurídico de cada período histórico. Os problemas são manifestos, portanto, na sua contextualidade. A partir desse raciocínio, pensa-se ser possível fazer uma investigação mais lúcida sobre a racionalidade jurídica que possui uma natureza extensa e variável.

É necessário deixar claro também que pela abrangência do objeto de estudo, restringiu-se em analisar a partir da Modernidade. Ponto de partida decidido, porque percebe-se que nesse momento que conseguiu-se observar uma gênese do que é considerado como racionalidade jurídica. Procurar a gênese, em outras palavras, significa buscar a origem. E entender o início é fundamental para compreender a nossa situação atual. O Direito brasileiro que tem variadas 
influências europeias e americana, apesar de hoje possuir sua identidade, é produto de uma pluralidade de racionalidade jurídica onde tem fontes, isto é, uma gênese em diversos sistemas e tradições jurídicas.

Em razão do objeto de pesquisa, qual seja: as decisões dos Tribunais Superiores (STF) nos chamados casos difíceis, em um segundo momento da pesquisa foi realizado uma identificação e compilação da jurisprudência. Em verdade, não se trata de um estudo de caso, mas sim verificar com que frequência certas doutrinas são citadas como componente da motivação judicial, bem como, influenciam na escolha do método ou técnica de interpretação.

Nesse sentido, a compreensão da racionalidade jurídica brasileira é um resultado final da pesquisa que foi feita de forma empírica para analisar qual a natureza do nosso Direito. A partir dos argumentos no campo do agir decisional nos votos do Supremo Tribunal Federal, pode-se ter uma ideia da nossa atual racionalidade jurídica. Os votos, de um período pré-constituição e pós-constituição de 1988, foram selecionados para tentar salientar a diferença entre duas racionalidades jurídicas. Maneira de investigar que está em conformidade com o nosso método que procura encontrar os paradigmas e seus confrontos. A comparação dos votos dos chamados casos difíceis a partir de um viés positivista e um viés pós-positivista deixa evidente uma mudança significativa do Direito.

\section{Revisão Bibliográfica}

\subsection{Formação da racionalidade jurídica}

Pensar num ponto originário de um certo tipo de racionalidade é uma tarefa árdua e necessita que seja descoberto uma mudança de paradigma do seu contexto social e político para assim, tornar claro identificar, a partir da mudança, o tipo de racionalidade que é manifesto nas diferenças, nos atritos que se formam enquanto eventos conflitivos entre um pensamento novo e aquele que está para ser ultrapassado ${ }^{2}$.

Neste sentido, observa-se uma cisão na forma pela qual o homem começava a construir o conhecimento na Modernidade. De certo, voltado numa dupla análise epistemológica, o racionalismo e o empirismo. Ambas as perspectivas

\footnotetext{
${ }^{2}$ KUHN, Thomas. Estruturas das revoluções científicas. São Paulo: Perspectiva, 2010.
} 
são sustentadas por um intermédio de validade para o conhecimento: o método ${ }^{34}$. Este instrumento de grande importância para a modernidade trouxe mais rigor e precisão na investigação da realidade. Com efeito, o método nesse período histórico serviu como um elemento fundamental para a constituição da razão, qualidade cerne de um argumento válido que variavelmente compõe uma verdade no intercâmbio do espaço e tempo. O legado que esse período histórico deixou para os pensamentos seguintes foi essencial para a formação da concepção jurídica no que diz respeito à natureza do Direito e, também, para legitimar a força do Estado, bem como sua forma de organização.

Às relativas intempéries, o pensamento da Modernidade, encontrou seu apogeu político-jurídico na Revolução Francesa, período em que se deu início a formação do Estado Liberal. Utilizando a razão secularizada como instrumento de combate às ideias que se encontravam em períodos medievos, os pensadores dessa época, os iluministas, condenaram a ideia de racionalidade até então construída por outras fontes de pensamento como o cosmológico e teológico. A fé, ainda que uma faculdade interpretativa e constitutiva para atingir uma forma conhecimento foi depredada pelo rótulo falacioso que se crescia pelos discursos científicos e racionalistas.

Evidentemente, a teologia conflitiva com as propostas dos iluministas 5 . Santo Agostinho e Tomás de Aquino, os quais elaboraram suas ideias tendo grande influência o pensamento grego, atuaram fortemente nessa forma de racionalidade tendo como faculdade principal a fé. Esta linha epistêmica, segue confluente ao pensamento dos antigos, em um curso natural, sem intervenção possível para o homem fruir sua vontade e sujeito à livre arbitrariedade dos Deuses e seus desejos.

A razão pensada nesse sentido é incongruente ao pensamento iluminista. Immanuel Kant criticou a natureza dessa razão que tirava do homem sua deliberação e liberdade ${ }^{6}$. Como principal argumento, para divergir à realidade estática e natural que esse tipo de racionalidade se baseava, Kant fez uma distinção do homem com os animais. Influenciado fortemente por Jean Jacques Rousseau, teorizou que o homem é capaz de pensar e refletir sobre suas escolhas muito além

\footnotetext{
${ }^{3}$ BACON, Francis. Novo Organon. São Paulo: Edipro, 2014.

${ }^{4}$ DESCARTES, René. O Discurso sobre Método. Rio de Janeiro: Vozes, 2006.

${ }^{5}$ Tomás de Aquino no seu livro "Suma teológica" deixa claro esse caráter religioso erguido através do pensamento clássico dos gregos antigos.

${ }^{6}$ KANT, Immanuel. Crítica da razão Pura. Rio de Janeiro: Vozes, 2012.
} 
dos animais que só vivem por determinações e desejos ${ }^{7}$. Frisou, com muita sabedoria, através de seus escritos que, com o uso da razão, a humanidade ganhou autonomia para pensar sua condição e não fazer o que o meio os condicionou. Para ele, dessa maneira, a razão constitui um instrumento fundamental para negar e criar novas condições àquelas que nos foram proporcionadas.

Para compreender melhor esse tipo de razão que Kant propõe, não pode-se deixar de abordar o conceito de maioridade. Como deixou-se claro acima, a liberdade é uma característica indispensável para o pensamento autônomo. O pensar de forma independente implica em se libertar do preconceito e de racionalidades vinculantes. Nesse sentido, pode-se entendê-la como a "vocação de cada homem em pensar por si mesmo" ${ }^{8}$. A essa transição da menoridade para maioridade, Kant denomina de esclarecimento. Esse último, que caracteriza um estado privilegiado, provém de pensamentos que não estão sujeitos a fórmulas e automatismos. Trata-se, portanto, em última instância, de uma reforma do pensamento. Sobre essa reflexão, Habermas aduz:

"A necessidade de emancipação é um ato originário de liberdade são pressupostos para que o homem possa se elevar ao ponto de vista da maioridade a partir do qual é possível então discernir criticamente o mecanismo de surgimento do mundo e da consciência" ${ }^{\text {. }}$

$\mathrm{Na}$ Modernidade que, portanto, pode-se falar em Jusracionalismo. A razão secularizada deu ao homem a liberdade para criar o mundo a sua vontade. Característica do qual fomenta um momento de transição e ruptura entre duas formas de razão e torna evidente também um diálogo entre a epistemologia e a política, qual seja, a transferência do rigor do método ao meio jurídico evidente nas atividades de políticas públicas (na época, ciência de polícia) e por um processo gradual de codificação de leis. Crescia neste sentido, um discurso de domínio por uma racionalidade cada vez mais burocrática subsidiada por um espírito científico. Não podemos deixar de atentar também que junto a essas mudanças o conceito de ordem tomava uma significação distinta para coadunar com a razão secularizada. $\mathrm{A}$ ordem é cada vez mais atrelada à artificialidade como resultantes do pensamento e

\footnotetext{
7 ROUSSEAU, Jean Jacques. Discurso sobre a origem e os fundamentos sobre a desigualdade entre os homens. São Paulo: Edipro, 2015.

8 Immanuel Kant. Resposta à pergunta: $O$ que é o esclarecimento. Disponível em:https://bioetica.catedraunesco.unb.br/wp-content/uploads/2016/04/Immanuel-Kant.-Oque-\%C3\%A9-esclarecimento.pdf . Acesso em: 25 de julho de 2017.

${ }^{9}$ HABERMAS, Jurgen. Teoria e práxis. São Paulo: UNESP, 2011, p. 476.
} 
ação do homem e não como um produto da harmonia da natureza.

A transição de um pensamento racional-teológico para um pensamento racional-científico, com efeito, paulatinamente, aumentava a formação de juristas letrados, tornando o Direito um objeto intelectual e sistematizado.

Paralelamente também se desenvolvia a simbologia da autoridade. $\mathrm{O}$ conceito de soberania de Jean Bodin centralizava o poder disperso e criava condições possíveis para governar ${ }^{10}$. A soberania fazia da gênese do poder estatal estar na própria figura da pessoa ou em uma instituição, ora tendo uma identidade divina, ora como a boca da lei. No século XVI, imerso no pluralismo jurídico (direito canônico, direito romano medieval e direito local), ainda arrastado por pensamentos teológicos, o conceito de soberania, evidentemente, serviu como instrumento de ruptura do Direito teológico com o Direito que, aos poucos, estava nascendo à luz do pensamento Jusracionalista.

Nessa onda de transformações, com a transferência do poder eclesiástico para o poder estatal mudava-se também como encarava-se o Direito, o qual tomava proporções políticas de forma a tornar indistinguível uma possível limítrofe entre a política e o Direito. O Estado, portanto, se expandia, pelos conceitos que iam surgindo como instrumentos artificiais para ditar uma ordem na sociedade, aliado à ciência da polícia que criava meios concretos e científicos para criar formas de organização de governo. Todas essas mudanças só foram possíveis graças ao pensamento subsidiado pela razão secularizada que agia em confronto e, subversivamente, ao pensamento religioso hegemônico.

Com efeito, a partir dessa nova forma de se ver o Direito, paulatinamente, o Estado Liberal mostrava suas nuances de atuação. O Jusracionalismo, neste sentido, foi uma expressão da razão secularizada ao pensamento jurídico evocado por várias medidas para se criar um Estado e um modo de governar, o qual foi fundamental, nesse mesmo sentido, para desenvolver o Juspositivismo como forma de trazer mais rigor à eficiência nas leis e, assim, criar capacidade para poder universaliza-la. No entanto, é necessário deixar claro que não se trata de uma ruptura entre paradigmas. Há uma certa linearidade conflituosa que distingue esses dois pensamentos jurídicos.

Para tratar desse tema com profundidade, se torna indispensável diferenciar o Jusracionalismo do Juspositivismo para verificar, posteriormente, como as duas

${ }^{10}$ BODIN, Jean. On Sovereignty. Cambridgeshire: Cambridge UK, 1992. 
vias de pensamento não possuem um caráter necessariamente antagônico. Podendo ter conceitos conflituosos, porém, não divergentes. Portanto, as duas linhagens jurídicas, mesmo apresentando particularidades, podem ter uma justaposição caso analisadas de forma holista. Será tratado, por conseguinte, os embates desses dois temas.

Analisou-se que o Jusracionalismo surgiu a partir de uma nova forma de se pensar o mundo que é aquela ordenada pela razão secularizada. E que com ela, foi possível configurar uma nova forma de se ver o Direito para criar vias concretas para se formar o Estado e uma organização de sociedade. Portanto, o Jusracionalismo foi um instrumento fundamental para casar o Direito com a política. Motivo pela qual, havia também a necessidade de se criar um poder que, apenas por uma via jurídica se mostrava impossível de se alcançar, visto que era intrínseco emanar tal poder de uma forma coercitiva para todos os indivíduos e isso exigia uma intervenção do Estado na vida social do povo ${ }^{1112}$.

No entanto, o crescimento do Estado de forma demasiada como ocorreu no Antigo Regime consolidando uma forma de governo político que hoje entendemos por Absolutismo, ia de encontro às fundamentações criadas a partir do Estado Liberal. Os princípios que constituíram a Revolução Francesa - Igualdade, Fraternidade e Liberdade - além da ideia de individualismo, se divergiam fortemente ao poder de um tirano, em grande parte, evocado do poder centralizado ${ }^{13}$.

Interessante avaliar que, ambas doutrinas, Estado Liberal e o Estado centralizado, para legitimar o seu argumento, tiravam justificativas do direito natural à procura de um motivo satisfatório para seu discurso de dominação. $O$ direito natural e o direito positivo vivem subsidiados um ao outro e em constante conciliação. Em nome de uma justiça ideal e um direito ideal, o direito natural protagonizou uma série de mudanças no sistema jurídico ${ }^{14}$. Essa razão Jusracionalista é uma forma de subversão que grande parte dos pensadores

\footnotetext{
${ }^{11} \mathrm{O}$ poder colocado aqui se entende por o que chamamos hoje de administração pública, porém, sem as devidas moderações que encontramos depois do estabelecimento do Estado Liberal.

${ }^{12}$ SEELAENDER, Airton. O contexto do texto: notas introdutórias à história do direito público na idade moderna. Revista Sequência, no 55, p. 253-286, dez. 2007

${ }^{13} \mathrm{~A}$ ideia do individualismo derivou do cartesianismo de Descartes "A definição do homem feita pelo cartesianismo era de um ser racional e livre [...] A combinação da razão e vontade, dois tributos evidentes do indivíduo, permitiam chegar a outro tributo do indivíduo - liberdade [...]".

${ }^{14}$ PEREIRA, Caio Mário da Silva. Instituições do direito civil. Rio de Janeiro: Forense, 2016
} 
utilizaram para quebrar o discurso hegemônico que era predominante em seu respectivo momento histórico. Pode-se perceber que isso ocorreu frequentemente em momentos de transição de pensamento, como por exemplo, o embate do Common Law com o rei legislador, o conceito de ordem para Idade Média e o conceito de ordem para Modernidade, o modo de governo Absolutista e o modo de governo Democrático-Liberal etc. ${ }^{15}$ A história do pensamento jurídico seguiu por uma série de rupturas, os quais necessariamente estavam ligadas a uma nova forma de imposição de poder.

A partir da análise do direito natural e do direito positivo, pode-se enxergar melhor que, na verdade, o Jusracionalismo e o Juspositivismo também não são conceitos antagônicos, mas qualidades jurídicas essenciais e coexistentes para buscar, gradativamente, um melhor ordenamento jurídico. Por isso, por uma série de pensamentos que exprimem sua intencionalidade, por vezes, podemos encontrar divergências, mas que em diálogo, enriquecem o debate jurídico. Tal fato deixa evidente o pluralismo dos saberes do Direito e serve como um instrumento pedagógico, visto que a racionalidade de um momento histórico é apreendida em diálogo com as contradições do seu tempo.

Em suma, o Jusracionalismo, surgido na modernidade, agrega um intenso juízo e desejo valorativo com o intuito de tentar mudar a realidade de acordo com sua vontade edificada por um pensamento, por vezes, idealista. A boa medida, pode-se relacionar o Jusracionalismo à uma ideia que tramita o inteligível e o metafísico onde, existiria, nesse lugar, uma espécie de gabarito, isto é, um mundo ideal que derivaria, a verdade absoluta. A partir dela, a medida do possível, buscarse-ia uma consonância dela com a realidade.

Ademais, pode-se entender o Jusracionalismo como uma razão instrumentalizada. Essa forma de pensar a realidade, qual surge com Bacon enquanto "saber é poder", ganha mais expressividade no âmbito das ciências humanas quando Hobbes fundamenta o conceito de Contrato ${ }^{16}$. Essa ideia de cunho Jusracionalista distingue o Estado natural do Estado civil, deixando evidente a potência da razão secularizada pela intervenção na natureza pelo homem. A formação do Estado era cada vez mais perceptível e a maneira pela qual se tornava

\footnotetext{
${ }^{15}$ Seelaender, Airton. A "polícia" e as funções do Estado - notas sobre a polícia do Antigo regime. Revista da Faculdade de Direito - UFPR, Curitiba, n.49, p-73-87, 2009.

${ }^{16}$ ROUSSEAU, Jean Jacques. Do contrato social. Rio de Janeiro: Vozes, 2017.
} 
uma instituição ditadora de regra criava coerção cada vez mais intensa sobre as leis. "(...) é evidente que a lei, em geral, não é um conselho, mas uma ordem" 17. A partir da mudança no conceito de ordem, artificial e instituída pelo homem, surgirá a ideia de se positivar a lei trazendo ao mundo jurídico um discurso fiel para legitimar uma forma de dominação com justificativa do seu posicionamento como autoridade regulada pela lei.

A racionalidade jurídica, nesse sentido, era instrumentalizada com o intuito de resolver problemas e conflitos. Max Weber percebe esse momento histórico tomado pela racionalização. Fenômeno que não era exclusivo às administrações públicas e decisões judiciais, mas que também se apresentava na sociedade civil $^{18}$. A natureza desse pensamento racionalizado de essência teleológica foi fundamental para estruturar o positivismo jurídico e construir a cultura jurídica de Austin, Bentham e Hart. José Reinaldo Lima Lopes confirma que:

"O ideal de uma ciência positivista, assenta-se na tradição idealista da filosofia do fim do século XVIII. Em primeiro lugar, define-se uma distinção entre sujeito e objeto do conhecimento e suas relações recíprocas. Em segundo lugar, propõe uma objetividade do conhecimento demonstrável pela manipulação e pela experimentação. Conhecer é saber fazer, é reproduzir e prever. A ciência é então destacada da interpretação e da razão prática, e associada à razão instrumental e ao cálculo."19

Por outro lado, quando se analisa o Juspositivismo, percebe-se uma natureza jurídica fortemente influenciada pela ciência. Nesse sentido, ela parte com o intuito de tratar a realidade como ela é, sem distorções valorativas e subjetivas, a partir de um método científico que preza, essencialmente, em ser objetivo e empírico, com o fim claro de tentar mostrar como de fato as coisas são e como elas realmente funcionam. ${ }^{20}$ Portanto, a principal diferença do Juspositivismo com 0 Jusracionalismo é do primeiro tratar da ciência descritiva; e o segundo da ciência prescritiva. $^{21}$

\footnotetext{
${ }^{17}$ HOBBES, Thomas. Leviatã ou matéria, forma e poder de uma república eclesiástica e civil. São Paulo: Martins Fontes, 2014.

${ }^{18}$ WEBER, Max. Ética protestante e o espírito do capitalismo. São Paulo: Companhia das letras, 2014.

${ }^{19}$ FARIA, José Eduardo. O direito na economia globalizada. São Paulo, Malheiros, 1999, p. 41

${ }^{20}$ Arnaldo Godoy no seu texto "O discurso sobre o método e do direito" afirma que o subjetivo é fundamental para o ato de duvidar.

${ }^{21}$ BOBBIO, Norberto. O positivismo jurídico. São Paulo: Ícone Editora, 1999.
} 
A leitura de "O Positivismo Jurídico" de Bobbio faz do entendimento do tema ser mais analítico. ${ }^{22}$ De acordo com ele, o positivismo jurídico se manifesta: "por uma teoria da coatividade do direito, segunda a qual as normas são aquelas feitas valer por meio da força; uma teoria da legislação como fonte proeminente do direito; uma teoria da coerência e completude do ordenamento jurídico, segundo o qual não pode haver num sistema jurídico lacunas ou antinomias; uma teoria imperativista do direito, que considera a norma como um comando do soberano e, ainda, uma teoria da obediência absoluta da lei enquanto tal"; uma teoria da separação do direito com a moral e por fim uma teoria do direito avalorativo. ${ }^{23}$ Não cabe no momento, fazer um análise de cada teoria do qual sustenta o positivismo jurídico. No entanto, sua enumeração já esclarece, ainda que de forma superficial, as características intrínsecas que formam o corpo do positivismo jurídico.

A partir desses aspectos, pode-se ver que o sentido de verdade que entende-se no Juspositivismo ganha validade uma vez que é promulgada ou outorgada por uma autoridade que detém o poder simbólico de soberania. Além disso, aliado a essa expressão política, o Juspositivismo constrói sua verdade a partir de métodos científicos que dão ainda mais rigor ao seu discurso de autoridade. O Juspositivismo, assim, anda de mãos dadas com a ciência e com a política. Por isso, a ideia de positivar a lei só é possível com o surgimento de uma instituição que detém controle sobre a sociedade. Fato impossibilitado na Idade Média, quando inexistia um Estado propriamente dito e as relações de poder eram descentralizadas. A esse ponto de organização, o sistema jurídico era plural e confuso. $O$ Juspositivismo, com efeito, foi essencial para centralizar o poder e formar o Estado para constituir uma única fonte onde derivaria a lei. Hobbes, para tanto, foi importante como precursor dessa linhagem jurídica. ${ }^{24} \mathrm{O}$ Direito inglês, porém, na época, possuía fortes vínculos à fontes tradicionais e locais. Essa duas expressões jurídicas se validaram por questões históricas. Hobbes combatia esses tipos de fontes de Direito para instituir o positivismo jurídico e restringir o poder legislativo à uma autoridade que, para Hobbes, melhor seria o rei. Como consequência, esse tipo de reforma jurídica organizaria as leis e sua validade, bem como sua aplicação. ${ }^{25}$

\footnotetext{
22 Ibidem.

${ }^{23}$ Ibidem.

${ }^{24}$ HOBBES, Thomas. Leviatã ou matéria, forma e poder de uma república eclesiástica e civil. São Paulo: Martins Fontes, 2014.

${ }^{25} \mathrm{O}$ grande adversário de Hobbes para implantar um sistema jurídico positivado foi Edward Coke, o qual defendia os direitos instituídos ao longo da história. Nesse confronto, Coke,
} 
No entanto, uma vez que tais teorias do Juspositivismo se intensificam, a monopolização da verdade pelas leis aumenta, o que implica numa construção de dogmas. O dogmatismo é, em outras palavras, o fator que suspende o pensamento autônomo e o elemento do qual diminui o despotismo pessoal. Ele está, portanto, em oposição ao esclarecimento.

Se levar o dogmatismo como um "retorno ao mundo fechado das imagens e poderes míticos que precisam ser asseguradas decisões prévias socialmente vinculantes sobre questões práticas." 26 como Habermas colocou, podemos entender os dogmas como uma regressão à razão secularizada. Motivo pela qual, nessas circunstâncias, o homem renuncia sua maioridade, a capacidade de pensar e de decidir

Num sentido análogo, avaliando-se por um ponto de vista social e cultural, 0 dogmatismo se manifesta de forma semelhante ao entendimento originário de ideologia, qual seja: "uma representação e interpretação da realidade com característica de não corresponder a ela. A ideologia seria, desta forma, uma falsa apresentação da realidade e [...] falso discurso." 27 Ainda mais, "a ideologia não seria um discurso ingênuo, submetido apenas a um processo de auto-engano, mas surge com a intenção de defender os interesses explícitos ou não de uma classe social dominante."2829.

Essa última, trata-se uma perspectiva marxista de ideologia que nos interessa enquanto é fonte de um pensamento institucionalizado, isto é, quando o Direito se apropria dela para assegurar seu domínio através de um discurso que gira em torno da "ciência positiva". ${ }^{30}$

O entendimento do dogmatismo em seu conceito originário, ajuda a compreender como ele se manifesta no âmbito jurídico. De certo, confluente a alguns aspectos do seu termo primário, pode-se definir o positivismo jurídico, de acordo com José Eduardo Faria, neste sentido:

para legitimar seu argumento e contrariar as ideias de Hobbes utilizou falsas argumentos e construções jurídicas. Não é tanto que Coke ficou conhecido como um dos maiores edificadores de mitos jurídicos, principalmente, quando utilizou a Carta Magna como uma Constituição para combater as ideias do Leviatã. No entanto, Coke ganha a disputa, por estar em maior conformidade com os interesses da época.

${ }^{26}$ HABERMAS, Jurgen. Teoria e práxis. São Paulo: UNESP, 2011, p. 486.

${ }^{27}$ STIELTJES, Claudio. Jurgen Habermas a desconstrução de uma teoria. São Paulo; Germinal, 2001, p. 35.

${ }^{28}$ Ibidem, p. 36.

${ }^{29}$ MARX, Karl. Ideologia alemã. São Paulo: Boitempo, 2007.

${ }^{30}$ Por "ciência positiva" entende-se a ciência do direito que investiga o direito positivo. 
"A funcionalidade da dogmática jurídica sempre esteve ligada diretamente associada à tripla capacidade do legislador (a) organizar coerentemente a legislação, dando-Ihe unidade e sistematicidade, (b) de individualizar os conflitos procurando atomizá-los para melhor dispersá-los e (c) de se expressar por meio de uma linguagem objetiva, clara e homogênea. [...] No limite, portanto, toda experiência jurídica é reduzida à dimensão estrita do dogma normativa e à pretensa racionalidade formal." 31

Exposto suas características, por vezes, o dogmatismo jurídico é associado ao positivismo jurídico. Porém, isso não é inteiramente correto. Na verdade, a racionalidade formal, a qual é subsidiária de uma "ciência positiva" que é confluente ao dogmatismo jurídico. Há que se levar em consideração, apesar das críticas pertinentes, que o positivismo jurídico abarca uma extensa conceitualidade. O Direito a partir da Modernidade, em sua larga história, teve pretensões científicas com o objetivo de universalizar e sistematizar suas práticas. Isso resultou em técnicas e idealismos jurídicos que acabaram por "projetar um conhecimento pretensamente objetivo recusando questões metodológicas que articulam os planos da explicação da realidade." ${ }^{32}$ É nesse sentido que uma parte do positivismo jurídico se torna um dogmatismo, na medida em que ele se torna um conhecimento acrítico.

No entanto, apesar da dogmática jurídica apresentar problemas pertinentes, a normatividade é indispensável ao Direito. Sem direitos políticos instituídos juridicamente, não há cidadania, Estado de Direito e acesso à justiça. A relevância da dogmática jurídica, por isso, se encontra a partir da existência formal de Direito, na prática da subsunção, na correlação da norma com os fatos e, principalmente, na certeza e na segurança jurídica. Porém, o que procura-se apontar aqui é, a despeito da importância da dogmática jurídica que levantou-se, o problema que Tércio Sampaio identifica como a astúcia da razão dogmática. ${ }^{33}$ Sobre isso, Lenio Streck afirma:

"No contexto da dogmática jurídica, os fenômenos sociais que chegam ao judiciário passam a ser analisadas como meras abstrações jurídicas, e as pessoas protagonistas do processo, são transformadas em autor e réu, reclamante e reclamado. [...] Nesse sentido, pode se dizer que ocorre uma espécie de coisificação (objetificação) das relações jurídicas." ${ }^{34}$

${ }^{31}$ EDUARDO FARIA, José. A crise do Direito numa Sociedade de Mudanças. Brasília: Editora UNB p. 14

32 Ibidem. p.15.

${ }^{33}$ SAMPAIO FERRAZ JR, Tércio. Introdução ao estudo do Direito. São Paulo: Atlas, 2003.

${ }^{34}$ LUIZ STRECK, Lenio. Hermenêutica Jurídica $e(m)$ Crise. Porto Alegre: Livraria do 
O resultado disso "é a interpretação totalmente alienada e afastada das relações sociais" ${ }^{35}$. O conteúdo das relações sociais, nessas instâncias, não é relevante para o ator jurídico, o que importa é a performance jurídica manifesta por uma boa hermenêutica. Pode-se apontar uma crítica ou, mais adequadamente neste sentido, uma crise da hermenêutica enquanto a própria prática do Direito e hermenêutica se torna puramente uma atividade estética.

É por isso que o Direito, que agrupa dentro do quadro das ciências humanas, não deve apelar excessivamente a metodologias da ciência da natureza, porque ele não trata apenas de questões de fato e neutralidade. Não basta para o Direito saber porque o homem é um animal social. Há que se saber o que implica em o homem ser um animal social. Com efeito, é necessário analisar, por vias subjetivas, o significado do homem ser um animal social. Para esse tipo de dúvida que é valorativa, a objetividade se torna insuficiente para a razão do Direito.

Esse tipo de reflexão nos leva para outro questionamento: o governo das normas é melhor que o governo da vontade arbitrária do homem? A história parece se repetir. Desemboca-se num problema que foi debatido na Modernidade. Se, em última instância, se torna importante avaliar de forma crítica e valorativa uma norma, coloca-se em pauta o critério de capacidade objetiva ou subjetiva do aplicador da lei.

Está-se diante do problema contemporâneo do decisionismo e normativismo. Duas posturas do Direito e duas racionalidades jurídicas distintas. Vamos seguir no próximo capítulo investigando esses dois pensamentos.

\subsection{Normativismo versus Decisionismo: Constitucionalismo ou vontade do soberano.}

Hans Kelsen e Carl Schmitt. Esses dois pensadores são os principais protagonistas da corrente do pensamento normativista e decisionista, respectivamente. A partir desses dois juristas, a pesquisa, neste capítulo, tem o objetivo de analisar temas como o conceito de soberania, ordenamento jurídico e o estado de exceção. A investigação desses assuntos, enseja, naturalmente, um dos pontos fundamentais da pesquisa: o que é a decisão judicial. Segue, portanto, um debate a respeito desses temas.

Para começar, será necessário analisar a posição de Hans Kelsen, um autor 
que, apesar de ser um doutrinador da vertente do Normativismo, apresenta algumas diferenças conceituais na forma de validade e eficácia da ordem jurídica. Diferente de pensadores do positivismo jurídico, como Austin e Bentham, Kelsen não coloca como eles, que a eficácia do direito se dá pelos mandamentos do soberano e que isso seria suficiente para explicar sua legitimidade. Em uma outra nuance positivista, Kelsen tenta justificar a legitimidade a partir de um "ponto de vista objetivo e universal, o dever-ser das normas jurídicas" ${ }^{36}$. Assim, flerta com a ideia de um ordenamento jurídico auto-referencial, afirmando que "uma norma é válida se e porque foi criada de uma certa maneira, que determina uma outra norma"; "por sua vez, esta norma também foi regulada por outras [...] e este andamento regressivo na norma fundamental - norma suposta [...] que funda e sela a unidade deste sistema de criação"37. A partir disso, Kelsen cria um sistema jurídico autorregulador que dará origem doravante à sistemas jurídicos autopoiéticos. ${ }^{38}$ Ademais, como a Constituição é a norma das normas dentro do ordenamento jurídico, ela é a base de toda legitimação do Estado.

A legalização é uma peça importante para Kelsen. Nesse sentido, apenas quando uma norma é registrada por vínculos de órgãos estatais, em concomitância, ela é válida. Essa perspectiva traz, por conseguinte, um outro autor sociólogo do século XX, Max Weber, para a discussão porque, no mesmo sentido, esse autor via a legalidade como fonte de legitimação das leis afirmando que "é a crença na legalidade, quer dizer, a disposição de obedecer a prescrições formalmente corretas e estabelecidas da maneira habitual" que formam a concepção do direito no Estado de Direito. ${ }^{39}$ A verdade, nesse sentido, estaria na norma que, com efeito, se mostraria concreta pelo comprimento pela sociedade. Portanto, "A legitimidade é o critério necessário para se distinguir o poder de Direito, do poder de fato (direito de governar), já a legalidade - como fundamento da forma de exercício do poder serviu ao longo da história para se diferenciar um bom governo do mau governo. E, a partir da intersecção do Estado de Direito, a legalidade demonstra a existência de

\footnotetext{
${ }^{36}$ MARYIOLI, Aglaé. Billier, Jean Cassien. História da Filosofia do Direito. São Paulo: Manole Ltda, 2005. pág. 208

${ }^{37}$ KELSEN, Hans. Teoria Pura do Direito. São Paulo: WMF Martins Fontes, 2011. p.

${ }^{38}$ Luhmann, doravante, cria sistemas jurídicos autopoiéticos para analisar sociologicamente a sociedade. Pode-se dizer que Kelsen muito influenciou esse pensador, uma vez que propôs novas vias do positivismo jurídico desconhecidas até então.

${ }^{39}$ Max Weber, Wirtschaft und Gesellschaft, Tübingen, 1925, p.19, citado por S.Cotta, "Éléments d'une phénoménologie de la légitimité", in Annales de philosophie politique, 7, 1967, p.63.
} 
um poder político juridicamente fundado." 40

O poder político juridicamente fundado que é a legalidade deixa evidente, na perspectiva de Kelsen, quem é o soberano. De certo, as normas. Ou se tratando do mais alto grau de soberania, a norma fundamental. O poder jurídico, no entanto, do jurista de Viena, só é possível tendo em vista uma situação de paz. É necessário, primeiramente, que seja estabelecido uma ordem. Uma vez estabelecido a ordem que as normas possuem um sentido. A normalidade é o fator primordial na decisão judicial kelseniana.

Schmitt, no entanto, é um autor que se interessa em questões de excepcionalidade, porque de acordo com ele, o papel da soberania fica obscurecido em condições de normalidade. Momentos de crise, para este autor, que definem o poder jurídico e quem detém monopólio da decisão. Por isso, o soberano será aquele que decide no estado de exceção. Todavia, "Esta definição pode ser apropriada ao conceito de soberania, somente enquanto este se assuma como conceito limite. Com efeito, conceito limite não significa conceito confuso como na terminologia espúria da literatura popular, mas sim um conceito mais relativo à esfera mais externa" 41 .

O fundamento do Direito para Schmitt se inicia com a decisão que doravante termina por estabelecer a ordem. Decisão que surge do nada, sem orientação contextual histórico-social, no entanto, com um fim claro de estabelecer organização. Dessa maneira, por motivos pertinentes, não é raro que sua fundamentação jurídica seja vista como um romantismo político. Neste sentido, ordenamento jurídico para o autor alemão designa decisão. "Para uma ordem legal fazer sentido, a situação normal deve existir e é o soberano quem definitivamente decide se esta situação normal realmente existe". A decisão é a fonte do direito e sua validade. É a própria força jurídica de criação do Direito.

É necessário deixar claro que Schmitt não é contra a legalidade. Ele apenas evidencia, em circunstâncias extremas de governo, quem tem a decisão última. Em conformidade com o Direito, a decisão se mantém como um conceito jurídico, não sendo, em sua totalidade, um instrumento político. Schmitt organiza seu pensamento

\footnotetext{
${ }^{40}$ CHEVITARESE, Alessia Barroso Lima Brito Campos. Controle jurisdicional do processo legislativo. Curitiba: Juruá, 2016. p. 47.

${ }^{41}$ MACEDO JUNIOR, Ronaldo Porto. O decisionismo jurídico de Carl Schmitt. Lua Nova, São Paulo, n. 32, p. 204, Apr. 1994.
} 
desse modo: "a decisão não é um elemento extra ou meta jurídico, externo ao direito, de significado apenas sociológico, mas, ao contrário, é um elemento formal especificamente jurídico. A decisão soberana é, assim, o elemento formal que dá fechamento ao sistema jurídico e, desempenha, neste sentido, a função análoga àquela desempenhada pela norma fundamental no sistema kelseniano."

Como bem salientou Porto Macedo Jr., trata-se, nessa abordagem de análise, de uma discussão em que a teoria da decisão judicial serve como mecanismo para fechar o sistema jurídico. Nesse sentido, pelo lado normativo, a norma fundamental tem a primazia do Direito sobre o poder; enquanto pelo lado do decisionismo, o soberano tem primazia do poder sobre o Direito ${ }^{42}$.

Destarte, a decisão judicial, de um lado, para Kelsen se inclina numa hermenêutica objetiva na subsunção; por outro lado, para Schmitt, mesmo em circunstâncias em que é possível haver uma possibilidade de equivalência de um fato com a norma, cabe ao soberano decidir e, subjetivamente, enunciar o Direito, resolvendo conflitos e proclamando a paz.

Investigou-se um pensamento do Direito ${ }^{43}$ muito arbitrário que pode dar margens para o crescimento do judiciário e do Estado. Além de não estabelecer limítrofes exatos de uma esfera de atividade entre poderes, configura uma de Teoria do Direito que possibilita formas de subjetivação do soberano que podem se demonstrar nocivas para o povo. Kelsen se atentou para isso e tomou medidas jurídicas para precaver esses tipos de infortúnios jurídicos. Será analisado, por conseguinte, como o jurista de Viena, tomou essas providências em seus pensamentos.

\subsection{Teoria Pura do Direito: o caráter anti-ideológico do pensamento kelseniano}

Pode-se perceber no século XX, uma expressão jurídica com o intuito primeiro de purificar o Direito de todas ideologias e ideias da ciência da natureza. Tal pensamento criado por Hans Kelsen era um reflexo de seu contexto histórico, tempos em que o Direito se confundia com a política e ideologias tornando $o$

\footnotetext{
42 PORTO MACEDO JÚNIOR, Ronaldo. O decisionismo jurídico de Carl Schmitt. Lua Nova, São Paulo , n. 32, p. 207, Apr. 1994.

${ }^{43}$ Referência feita ao pensamento de Schmitt.
} 
judiciário arbitrário e subjetivo. A pretensão desse autor em criar uma Teoria Pura do Direito, em outras palavras, significava desvincular o Direito de qualquer forma de interesse político, tendo em vista que ideais políticos, por natureza, possuem uma carga valorativa. A supressão axiológica do Direito e a criação de uma metodologia pura e livre de qualquer outra base do conhecimento estruturava o conceito de ciência para Kelsen.

A ciência do Direito de Kelsen é sustentada por essas características, não corresponde ao conceito de ciência que predomina-se hodiernamente. Atualmente atribui-se uma qualidade científica a métodos rigorosos que herdaram-se da modernidade. ${ }^{44}$ Para tanto tornar possível através desses meios inferir uma dualidade verdadeira ou falsa.

O sistema jurídico kelseniano supõe um prenúncio autopoiético, de um organismo burocrático que trabalha independente em função da efetividade da criação de leis submetida a uma lógica formal. A justiça e o direito natural, instrumentos simbólicos para criação de um Direito "justo" e "ideal" são produtos do ofício político por, naturalmente, serem subjetivas. As leis válidas, de acordo com essa metodologia de Kelsen, são justas e verdadeiras por já terem passado por um processo científico de integração ao ordenamento jurídico. $O$ aparelho jurídico já incorpora as qualidades fundamentais tais como a justiça, restando a ele a subsunção ao caso concreto.

A ciência do Direito para Kelsen diz respeito principalmente a metodologia de criação de leis. Com efeito, é ocorrente que uma noção de ambivalência e até mesmo uma noção conflitante da ciência surja àqueles que se dedicam ao estudo da ciência de acordo com a sua definição estrita. Karl Popper difundiu o conceito de ciência propondo suas razões de fundamento no erro e na falseabilidade de uma tese e não na certeza de um conhecimento irrefutável, mas sim de que todo conhecimento é conjectural. ${ }^{45}$ Kelsen ao nos introduzir seu pensamento de formação de leis não se insere nessa discussão. Conclui-se que o autor da Teoria Pura do Direito cria seu próprio conceito de ciência. Conceito que se volta unicamente a satisfação do positivismo jurídico - da metodologia e não um fundamento científico. ${ }^{46}$

\footnotetext{
${ }^{44}$ Refere-se principalmente ao método cartesiano e baconiano. Os pilares da edificação o pensamento racional e científico.

${ }^{45}$ POPPER, Karl. A lógica da pesquisa científica. São Paulo: Cultrix, 2013.

${ }^{46}$ KELSEN, Hans. Teoria Pura do Direito. Coimbra: Armênio Amado, 1976.
} 
Além disso, é necessário expor que as ideias de Kelsen foram fundamentais para reinventar o Direito. No sentido de tornar o Poder Judiciário, uma instituição anti-ideológica. A percepção de Kelsen, em face aos acontecimentos de seu período histórico, o levou a entender o perigo de um poder majoritário e democrático. A democracia perdia sua rigidez funcional pela sua definição cada vez mais ser incerta, o que possibilitou a sua instrumentalização pela demasiada abstração. A democracia, com efeito, se tornava um conceito de retórica, de mera disputa intelectual. Se fazia mister, portanto, falar de uma forma precisa, científica e, até certa medida, estática. Kelsen via essa necessidade de falar do Direito de forma concreta, diminuindo o máximo possível a ambiguidade. As cláusulas pétreas são, por exemplo, um modo de falar do Direito com exatidão, pois define precisamente 0 que caracteriza condições para um Estado de Direito e o funcionamento da democracia. Assim, torna-se difícil que um detentor do poder popular, em nome da justiça ou outra forma de ideologia, renuncie certas questões fundamentais de governo e sociedade. A reflexão de Kelsen é clara nesse sentido, não se iludir nas tentações da metafísica.

Ademais, o poder judiciário, na perspectiva de Kelsen, atuaria de uma forma independente e não necessariamente em correspondência com o povo. Para quando necessário, responder às exigências da minoria. Portanto, os órgãos jurídicos apesar de não serem representativos, funcionam com auxílio de uma racionalidade jurídica que manifeste o interesse e a boa fé de determinados grupos sociais.

No entanto, não obstante de o pensamento de Kelsen trazer inúmeras contribuições para o Direito, pode-se perceber certas contradições nas suas formulações. Uma delas é o fato de, apesar de negar a metafísica, através do seu positivismo jurídico, o autor faz da essência do seu pensamento ser sustentada por uma ideia fictícia, a norma hipotética fundamental. Porém, Kelsen reavalia sua teoria "[...] um mínimo de metafísica e, aqui, de Direito natural, sem os quais não seria possível nem uma cognição da natureza, nem do Direito. Assiste-se, pois, à incorporação da ideologia, agora em seu indesejável sentido metafísico, à Teoria Pura do Direito". 47

Os avanços científicos que decorreram no âmbito das ciências da natureza eram um espetáculo de grande espanto para os doutrinadores da área jurídica. $\mathrm{O}$ 
discurso científico ditado por esses cientistas asseguravam, com muito otimismo para sociedade, saúde e prosperidade, que poucos ousavam em contestar. Qualidades que pouco se presenciou no mundo jurídico, em que muito se lutou para estabelecer um ordenamento jurídico que prevalecesse $e$, por conseguinte, centralizasse uma instituição legislativa para regular a sociedade. Não obstante, mesmo depois de sucessivas evoluções no Direito, pode-se perceber muitas dificuldades no mundo jurídico. A obediência enunciada como um fim pelas normas do Estado sempre encontrou fortes divergências, muito diferente do que se mostrou com a ciência, visto que todos ou uma maioria arrasadora das pessoas, tendem a acreditar, seguir e obedecer o que ela enuncia. Com grande credibilidade e receptibilidade, pode-se ver que o discurso da ciência se mantém válido e eficaz desde seu início à tempos atuais.

Esse caráter da ciência se mostrava um tanto atraente aos juristas. A filosofia analítica foi uma disciplina do qual dialogou com o empirismo científico e contribui para enriquecer o conhecimento jurídico. De certo, através da sua natureza investigativa. As análises dos filósofos analíticos sobre a realidade versavam com exatidão sobre a linguagem. ${ }^{48}$ Tema de importantíssimo valor para o Direito tendo em vista os problemas com a ambiguidade e antinomia.

Sobre a influência da filosofia analítica no Direito, gradativo era o aumento de juristas analíticos com objetivos de buscar exatidão e clareza na linguagem. Percebemos isso, dado às observações, nas mudanças de paradigmas no Direito que veremos mais para frente. Daremos sequência para pesquisa analisando os problemas da linguagem e seus efeitos na esfera jurídica. Para falar melhor dessa problemática, será abordado algumas perspectivas do Círculo de Viena, o qual foi um grupo de intelectuais associado à construção de um pensamento científico, e que também estudaram a linguagem como um meio fundamental para entender a realidade.

A filosofia analítica, na época, influenciou em grande parte o pensamento dos intelectuais do Círculo de Viena, principalmente devido a obra do filósofo Ludwig Wittgenstein - Tractatus-Lógico-Philosophicus. ${ }^{49}$ Apesar de Wittgenstein não estar dentro desse grupo de estudo, seus escritos eram de grande valor para eles, uma

\footnotetext{
${ }^{48}$ Pode-se citar aquí, como exemplo de filósofos analíticos, Herbert Feigl, Karl Menger, Ludwig von Bertalanffy.

${ }^{49}$ WITTGENSTEIN, Ludwig. Tractatus-Lógico- Philosophicus. São Paulo: EDUSP, 2001.
} 
vez que, como mencionado anteriormente, em função de se valerem de um método científico, prezavam, com muito rigor, pelas formas objetivas para se alcançar o conhecimento. Vamos analisar agora, porque a filosofia de Wittgenstein corroborou para o objetivismo jurídico.

Para analisar, porém, o pensamento de Wittgenstein que é inquestionavelmente complexo e extenso, precisa-se se ater ao essencial que tal qual vai, com efeito, manifestar algum impacto na esfera jurídica. Portanto, a pesquisa se restringiu em investigar o que ele chama de proposição factual e suas teorias que o fundamentam.

Com proposição factual, Wittgenstein diz respeito às coisas que são representáveis pela linguagem, ou seja, a construção de uma linguagem que torna possível uma denominação e, por conseguinte, uma atribuição de sentido à realidade. Assim:

"Toda linguagem é figuração do mundo. A linguagem - agora é já possível perceber - encontra seu apoio no mundo. Se assim não fosse, as proposições seriam destituídas de sentido [...]", " [...] Na perspectiva adotada no Tractatus, a linguagem sempre está referida ao mundo. E só adquire validade quando fundamenta uma imagem do mundo, isto é, dos fatos. Mas para que isso ocorra, uma exigência deve ser respeitada: os fatos têm de ser retratadas com total exatidão [...]". ${ }^{50}$

Nesse raciocínio, pode-se ver que "Wittgenstein concebe o conhecimento objetivo como manifestação de um fato que se expressa na linguagem e dentro dos limites desta. Tal linguagem deve ser perfeita e para isso faz se necessário construíla sob enunciados verdadeiros, que exprimem, portanto, a realidade." ${ }^{51} \mathrm{O}$ conceito de linguagem construída por Wittgenstein evidencia uma forte correspondência dos fatos com a fala. E, por conseguinte, nos fornece admissibilidade para atribuirmos a ideia de verdadeiro ou falso para o enunciado e, com efeito, a capacidade de serem trabalhadas logicamente. Nessa história, há uma forte correlação com o que chamase de ciência do direito com a linguagem analítica que acabamos de abordar, uma vez que o estudo jurídico guiado por aquela é embasado por um rigor metodológico científico, subsidiado, ao máximo possível, pelos fatos ${ }^{52}$. O que torna cabível, como

50 GRAÇA NETO, Antônio. Kelsen e Wittgenstein: as interfaces da lógica. Sequência: Estudos Jurídicos e Políticos, Florianópolis, p. 115-123, jan. 1996.

${ }^{51}$ GRAÇA NETO, Antônio. Kelsen e Wittgenstein: as interfaces da lógica. Sequência: Estudos Jurídicos e Políticos, Florianópolis, p. 115-123, jan. 1996.

${ }^{52}$ Principalmente, estudos feitos pelo positivismo jurídico. 
consequência, falar em um discurso jurídico verdadeiro ou falso, porque também, implica, no fim, de uma análise lógica. ${ }^{53} \mathrm{~A}$ ciência do direito, nesse sentido, vai estar em conformidade com a linguagem Wittgensteiniana. Por isso, constata-se uma forte influência do objetivismo na construção do conhecimento jurídico.

É necessário abordar essas questões científicas que tange o Direito, sobretudo, como fez-se através do ponto de vista da linguagem, porque na contemporaneidade a pretensão de conhecimento jurídico se distingue da Modernidade. De certo, distinta a partir da fundamentação epistemológica. Hoje, como pode-se perceber depois das análises feitas nos capítulos anteriores, não parte-se de um acesso ao conhecimento de forma imediata, como um suposto estado privilegiado de consciência. O norte subjetivo não satisfaz as nossas demandas para conhecer o mundo e resolver conflitos como na Modernidade. Por isso, não se trata de um problema que se resume ao "penso, logo existo" ${ }^{54}$. De uma forma semelhante, ao investigar-se por uma via puramente objetiva e lógica no que concerne a ciências humanas, também não tem-se resultados inteiramente convincentes no âmbito jurídico. Motivo pela qual exige-se, além da descrição de fatos, significações ${ }^{55}$.

Nesse sentido, na contemporaneidade, ao deparar neste problema, presencia-se uma virada a onto-linguística do conhecimento jurídico ${ }^{56}$. O Direito confluente as mudanças paradigmáticas, se vê fadado a implementar conceitos dos quais convergem com as exigências do nosso tempo. Essa guinada para uma nova construção do conhecimento jurídico é feita mesclando elementos objetivos e subjetivos. Não há uma acesso ao conhecimento inteiramente dado pelo intelecto ou pelas experiências. Mas um conhecimento estruturado por mediações. A isso, caracteriza-se como uma produção intersubjetiva do conhecimento. Para, no entanto, concretizar a intersubjetividade, ela requer de antecedência, palcos democráticos, porque manifestam sobretudo na relação inter-humana, o compromisso com a verdade. Evidentes quando alcançado o consenso e a compreensão crítica dos fatos. A condição de verdade nessas instâncias é o

${ }^{53}$ Fazer uma análise lógica implica necessariamente em poder falar sobre uma dualidade verdadeira-falsa e, uma vez que está-se a observar fatos, há sempre uma iminente mudança de constatação em função da falseabilidade. Wittgenstein, nesse sentido, chega a falar que "os limites da minha linguagem significam os limites do meu mundo".

${ }^{54}$ DESCARTES, René. Meditações Metafísicas. São Paulo: Edipro, 2016.

${ }^{55}$ Explicado no capítulo Formação da racionalidade jurídica.

56 STRECK, Lenio L. O que é isto? Decido conforme minha consciência. Porto Alegre: Livraria do Advogado, 2012. 
argumento que cria maior assentimento de todos os participantes do discurso.

A intersubjetividade é produto de uma mediação da linguagem. Não é coincidência que Dworkin afirma o Direito ser um fenômeno social e argumentativo. ${ }^{57}$ Podemos dizer, com efeito, que a racionalidade da contemporaneidade é edificada por uma razão comunicativa. Habermas é um dos precursores desse pensamento. ${ }^{58}$ Este tipo de racionalidade jurídica democratiza o Direito pela retórica. Sem, todavia, suspender racionalidades formais que dão o corpo para democracia e um Estado de Direito.

A esse ponto, a separabilidade do Direito e da moral que é uma das teses da objetividade epistemológica jurídica do positivismo jurídico clássico, parece insustentável. A despeito de todo empreendimento por parte de alguns juristas positivistas, podemos observar que Kelsen sabia dessa impossibilidade. Razão pela qual observamos a ciência dele de que o Direito é refém da subjetividade da linguagem natural. Tal separação seria razoável quando em um nível de linguagem pelo qual se diz os conjuntos enunciados, o qual se refere, o autor não faz parte. É um modo de fazer um olhar puro do olhado que é impuro. Trata-se de uma análise de uma metalinguagem sobre a linguagem. A separação total exigiria uma linguagem formal de segundo plano que é incondizente com a aplicação do Direito que, em sua natureza, discorre sobre o conteúdo dos fatos e seus significados. Não se tratando de meras fórmulas de referencialidade universal.

Em suma, a fundamentação do Direito na contemporaneidade segue por mudanças paradigmáticas devido a crise do positivismo científico, a percepção da inclusão da moral no sistema jurídico e possíveis insurgências de diversas racionalidades jurídicas. A esfera jurídica é, por isso, evidentemente, líquida, sujeita a movimentos e oscilações que dão uma roupagem nova ao Direito a cada momento. Com efeito, se o Estado, a comunidade jurídica e a cultura jurídica não tomarem medidas correspondentes às mudanças, o Direito mostrará sua leveza e insustentabilidade. Tema que será analisado no capítulo seguinte. Trata-se sobretudo de um debate ontológico do Direito.

${ }^{57}$ DWORKIN, Ronald. O império do direito. São Paulo: Martins Fontes, 2007.

58 HABERMAS, Jurgen. Direito e Democracia: entre facticidade e validade. Rio de Janeiro: Tempo Brasileiro, 1997. 


\subsection{Ontologia do Direito: insuficiência da racionalidade jurídica?}

A medida que a racionalidade jurídica ganha espaço na esfera jurídica, razões de natureza metafísica se tornam cada vez menos presentes no pensamento dos juristas. Na contemporaneidade, isso se torna manifesto em função de um pensamento dialético estar cada vez mais evidente no cotidiano do cidadão ${ }^{59}$. Por dialética, pensa-se, assim como na metodologia utilizada na pesquisa, "o modo de compreendermos a realidade como essencialmente contraditórias e em permanente transformação"60. O Direito, sob o efeito do movimento e das mudanças, agrega um caráter cético, a saber, em dois sentido relevantes para lidar com as alterações do tempo: a prudência, sustentado por uma perspectiva realista e um ceticismo metodológico. O primeiro designa atividade jurídica assentada em instituições jurídicas e por normas. O segundo, trata de questões que concerne a interpretação. De certo, pelo método denominado convencionalismo, o qual é proposto pelo positivismo jurídico principalmente do século XX.

A seguir, será analisado o convencionalismo, porque a partir dele, pode-se visualizar uma possível insuficiência do racionalismo jurídico e seu conflito entre uma nova forma paradigmática do Direito. Para fazer isso, todavia, é necessário debater sobre o positivismo jurídico novamente.

$\mathrm{Na}$ análise que fez-se até agora, pôde-se observar que a interpretação de Kelsen é convencionalista e dá margem, em última instância, para discricionariedade em casos difíceis. Para lidar com esse tipo de conflito, o poder judiciário trata de usar padrões extrajurídicos para fazer novos direitos em decorrência da inexistência de normas capazes de subsunção. No entanto, tal forma de interpretação suscita insegurança jurídica. Pode-se apontar duas razões claras para esse fomento: ausência de precedentes históricos e uma falta de racionalidade para se fundamentar e justificar uma decisão judicial em função dela ser explicitamente subjetiva e política.

"A partir de Kelsen e Hart, diagnosticou corretamente a textura aberta do Direito, ou seja, o fato de que o processo de interpretação e aplicação do direito não leva a uma única resposta correta, mas, pelo contrário, conduz a uma pluralidade de soluções igualmente admitidas

\footnotetext{
${ }^{59}$ A dialética é um pensamento que faz simbologia ao movimento, característica que está em oposição à metafísica em virtude desta ser um conhecimento "parado", assentado na fixação do conhecimento. Portanto, a presença do pensamento dialético implica num ensejo de mudança paradigmática para entender a realidade.

${ }^{60}$ KONDER, Leandro. O que é dialética. São Paulo: Brasiliense, 1981, p. 8.
} 
dentro da moldura jurídica conformada pelas regras e princípios contidos no ordenamento" 61

Interpretação essa do convencionalismo contudo, na verdade, tem pretensões de estabelecer segurança jurídica, mas acaba, em última instância e em casos excepcionais, levado ao discurso de autoridade e discricionariedade. No ponto de vista do Dworkin, esse tipo de interpretação acaba resumindo o Direito a algo puramente empírico "baseado em convenções pretéritas e não teórico", já que os positivista não se engajaram rigorosamente em desenvolver um método teórico e racional de interpretação ${ }^{62}$. Dworkin, com efeito, aponta sobre o convencionalismo:

"O Direito nada mais é que aquilo que as instituições jurídicas, como as legislaturas, as câmaras municipais e os tribunais, decidiram no passado. [...] Portanto, as questões relativas ao direito sempre podem ser respondidas mediante o exame dos arquivos que guardam os registros da decisões institucionais. [...] Em outras palavras, o direito existe como simples fato, e o que o direito é não depende, de modo algum, daquilo que ele deveria ser (questões de moralidade e fidelidade, não de direito)."63

O Direito, nessas instâncias, é reduzida a experiência, de tal forma que a fundamentação da decisão é feita sobre um discurso subjetivo e sem uma manifesta argumentação racional. ${ }^{6465}$ É nesse sentido que ele aponta que a decisão judicial passa a ser "[...] apenas uma questão daquilo que os juízes tomaram no café da manhã."66.

${ }^{61}$ CARVALHO, Juliana Brina Corrêa Lima de. Sobre os Limites da Argumentação Jurídica. Revista de Direito Brasileira, [S.I.], v. 2, n. 2, p. 47-94, oct. 2012. ISSN 2358-1352. Disponível em: <http://www.rdb.org.br/ojs/index.php/rdb/article/view/73>. Acesso em: 12 Aug. 2017. doi:10.5585/73.

${ }^{62}$ Castro Coura, A.;Taufner Zanotti, B .(Pós)Positivismo jurídico e a Teoria do Direito como integridade de Ronald Dworkin. Nomos, Fortaleza, v. 34, n. 2, p. 58, 2014.

63 DWORKIN, Ronald. O império do direito. Tradução de Jefferson Luiz Camargo. São Paulo: Martins Fontes, 2007, p. 10.

64 "A vida do direito não tem sido lógica: tem sido experiência. As necessidades sentidas em todas as épocas, as teorias morais e políticas que prevalecem, as intuições das políticas públicas, claras ou inconscientes, e até mesmo os preconceitos com os quais os juízes julgam, têm importância muito maior do que silogismos na determinação das regras pelas quais os homens devem ser governados. O direito incorpora a história do desenvolvimento de uma nação através dos séculos e não pode ser tratado como se compreendesse tão somente axiomas e corolários de livros de matemática. De modo a se saber o que é o direito, deve se saber o que ele tem sido e qual a tendência que há de se transformar. Deve se consultar alternativamente a história e as teorias jurídicas existentes".

${ }^{65}$ HOLMES, Oliver Wendell. The Common Law. Minnesota: GALE M. M. LAW, 2010.

${ }^{66}$ DWORKIN, Ronald. O império do direito. Tradução de Jefferson Luiz Camargo. São Paulo: Martins Fontes, 2007, p. 187. 
A crítica que Dworkin faz, por conseguinte, diz respeito em tratar o Direito, conduzido por uma interpretação convencionalista, fixado em "regras semânticas previamente compartilhadas" que induz a uma natureza estática e inflexível da atividade jurídica ${ }^{67}$. A esse estado jurídico, o teórico americano denominou de "aguilhão semântico". O Direito como interpretação é uma alternativa, uma saída para compreender o Direito de uma forma mais abrangente e menos rígida àquela posta pelo positivismo jurídico. A compreensão da natureza do Direito, nesse sentido, muda aos poucos à medida que é repensado a forma de decisão judicial mediante ao modo como é feita a interpretação.

Com efeito, o pós-positivismo que ganha intensidade no século XX é uma manifestação de inserção de princípios para resolver os conflitos em casos difíceis. Os princípios, pode-se dizer, seguramente, na contemporaneidade servem como o principal instrumento pela qual se forma a interpretação. Diferente da regra, os princípios não possuem um caráter "de tudo ou nada" na sua aplicação, e são vistas como normas, porém, de diverso conteúdo, normas de caráter indeterminado. Essa característica dos princípios dá uma extensa margem para interpretação, bem como abertura de uma possibilidade jurídica de criação de leis para os juízes. Portanto, pode-se perceber uma nova paradigmática do Direito. Sobre isso, Alexandre de Castro Coura e Bruno Taufner Zanotti aduzem:

"[...] a abertura principiológica do Direito se mostra como um caminho sem volta. Diferentemente do positivismo jurídico, que busca, nos casos limítrofes, um fundamento externo ao Direito, uma visão aberta e principiológica se torna o próprio fundamento jurídico desse —novo sistema. Mesmo as regras supostamente claras possuem um viés principiológico, pois o caso concreto - único e irrepetível — pode trazer uma nova possibilidade para essa regra que não foi anteriormente imaginada". ${ }^{68}$

Para propor uma interpretação racional com princípios, Dworkin propõe um juiz ideal, denominado juiz Hércules. Este ator jurídico, em consonância com uma comunidade engajada com a justiça, com princípios de equidade e devido processo legal adjetivo busca identificar os direitos evidenciados pela sociedade. A sociedade é vista, nesse raciocínio, como uma comunidade personificada confluente as competências do juiz. A função da atividade jurídica, nestas circunstâncias, seria

\footnotetext{
${ }^{67}$ Castro Coura, A.;Taufner Zanotti, B .(Pós)Positivismo jurídico e a Teoria do Direito como integridade de Ronald Dworkin. Nomos, Fortaleza, v. 34, n. 2, p. 58-59, 2014.

${ }^{68}$ Ibidem. p. 59.
} 
captar as exigências e transpor em ordens normativas. Por isso, a interpretação deixa de ser totalmente discricionária e subjetiva, na medida em que ela segue padrões institucionais e uma linearidade histórica. A noção de Direito como integridade proposto pelo autor americano é mediado pela "construção complexa da história da prática materialmente justificada por princípios voltados para um futuro que busca o Direito pela sua melhor luz" ${ }^{2}$. O "romance em cadeia" se trata dessa observação e atividade jurídica do juiz que se dá por uma interpretação construtivista.

Porém há que se expor que no fim, tal tipo de sociedade, bem como a presença dessa figura de juiz Hércules inexiste. Trata-se de um puro idealismo jurídico. Dworkin era ciente disso. Sua tese tinha finalidade, contudo, de apontar à comunidade jurídica em repensar as formas de interpretação, visto que 0 convencionalismo não proporciona justificativas jurídicas convincentes para uma decisão judicial.

As reflexões de Dworkin são fundamentais para repensar a natureza do Direito, uma vez que a inclusão de princípios como direitos juridicamente fundados estendem a atuação do judiciário para além do que ele é ordinariamente entendido. No entanto, ao visto até agora, não se resolveu a problemática da interpretação racional. Dworkin, não obstante de sua originalidade em ver o Direito como integridade, não resolveu por completo a causa que deu iniciativa. Precisamos, por conseguinte, continuar a procurar por pensadores que buscaram, a medida do possível, resolver ou aumentar a racionalidade na aplicação do Direito.

Um pensador que ganha destaque no modo pela qual se faz a aplicação de princípios é Robert Alexy. Pelo sopesamento, este autor tentou atribuir racionalidade ao modelo de ponderação no que concerne a colisão de direitos fundamentais. Os princípios, diferentemente das regras que marcadamente se expressam juridicamente pelo "tudo ou nada", pelo fato de poderem ser sopesados, bem se enquadraram numa ideia de ponderação.

"A aplicação de princípios exige, portanto, um procedimento de ponderação, de modo que, em face de uma colisão, o valor decisório seja dado ao princípio de que tiver maior peso relativo no caso concreto, sem que isso signifique a invalidação do princípio de peso menor." 70

\footnotetext{
69 Ibidem. p. 65.

70 CARVALHO, Juliana Brina Corrêa Lima de. Sobre os Limites da Argumentação Jurídica. Revista de Direito Brasileira, [S.I.], v. 2, n. 2, p. 47-94, oct. 2012. ISSN 2358-1352.
} 
Além disso, os valores são elementos dos quais coexistem com os princípios. Os valores qualificam as normas quais são indeterminadas. E neste sentido, a evocação de direitos por meio de princípios democratiza o acesso à justiça.

Porém, nem em nome da justiça o juiz pode sujeitar a valorações morais e totalmente subjetivas. Na resposta destas questões, pode-se apontar "(a) a ideia de que quem decide deve ajustar-se aos "valores da coletividade ou de círculos determinados"; (b) o recurso ao "sistema interno de valorações do ordenamento"; (c) o apelo a uma "ordem concreta de valores" ${ }^{\prime 1}$. Há, portanto, mesmo que de forma breve e não muita exata, uma forma de objetivação dos valores. É necessário deixar claro também que para Alexy "princípios não são valores, porque apontam para o que é devido, enquanto os valores apontam para o que pode ser considerado 0 melhor. Não obstante, princípios se equivalem a valores, no sentido de que ambos possuem operacionalização idêntica. Os princípios são, pois, normas que comandam a realização de valores"72.

Nesse sentido, pode-se perceber que a aplicação de princípios é restringida por instituições e por um interesse público. Os princípios, por isso, são de certa maneira, ou pelo menos em tese, uma forma de democratizar os direitos que não são produzidos pelo poder legislativo em virtude da falta de consenso e apoio político no parlamento. Dessas mudanças, a natureza do judiciário se torna algo incerto sendo necessário repensar as suas competências. A qualificação tripartida de poder desenvolvida por Montesquieu na Modernidade começa a sentir seus déficits basilares de sustentação à demanda de uma nova forma de proposição do que é o Direito ${ }^{73}$.

O surgimento dos princípios e sua natural tendência em ser vista propriamente como um Direito abala toda a cultura jurídica, principalmente a brasileira, a qual é assentada por influências romano-germânica. Por isso, visualizase de forma tênue uma crise do Direito por uma razão de natureza teórica, visto a dificuldade de definir as limítrofes da atividade jurídica. Para tanto, visando repensar o Direito, é necessário indagar se os princípios, como uma norma indeterminada

Disponível em: <http://www.rdb.org.br/ojs/index.php/rdb/article/view/73>. Acesso em: 12 Aug. 2017. doi:10.5585/73.

71 lbidem. p. 61.

72 Ibidem. p. 62.

${ }^{73}$ MONTESQUIEU, Charles. O espírito das leis. São Paulo: Martins Editora, 2005. 
instituída juridicamente, possui um caráter formal. Ainda mais, questionar se a atenção à substancialidade e eficácia de uma norma indeterminada (princípio) torna legítimo o poder judiciário intervir em outros poderes são questões que se mostram saliente para o Direito contemporâneo em crise.

Aliado a isso, "a falta de segurança na prática jurídica, da incerteza dos julgamentos, do arrastar das questões, da indisciplina da orientação, da confusão dos padrões de decisão" são problemas que repercutem no sistema jurídico atual no âmbito prático ${ }^{7475}$. A partir desses problemas, a existência institucional jurídica se dinamiza por afluir em diversos campos de ações do homem. O fenômeno de complexificação do Direito é dado, nesse sentido.

O Direito, nessas instâncias, por um lado, manifesta sua leveza e evidencia a sua organicidade e o fato de que deve se estudá-lo atento às oscilações políticas e culturais. Por outro lado, mostra como o pensamento dialético deve ser levado a sério quando trata do conhecimento jurídico, o qual é contingente e contraditório.

Viu-se, porque o conhecimento jurídico é contingente. De certo, pela verdade construída por meios intersubjetivos conduzidos por uma razão comunicativa $^{76}$. Porém, não foi analisado por que ele se mostra contraditório na contemporaneidade. Será investigado, por conseguinte, criticamente, nesse sentido, o motivo da racionalidade jurídica proposta por Alexy através da ponderação de valores acabar sendo irracional.

Apesar dos princípios apresentarem pontos positivos quais são facilmente identificáveis, há, no entanto, a necessidade de controlar o seu uso. É evidente essa exigência uma vez que em circunstâncias desnecessárias o juiz faz a sua aplicação. Portanto, pode-se observar uma hipertrofia de princípios na prática jurídica ${ }^{77}$. 0 sopesamento se torna, a medida que ganha relevância enquanto norma, uma saída fácil para qualquer resposta. Além de ensejar segurança para o aplicador escolher, numa gama de possibilidades, uma justificação que, por sinal, não tem uma

\footnotetext{
${ }^{74}$ Roberto Freitas Filho argumenta que vivemos numa era de transição de paradigmas jurídicos. Presencia-se no sistema jurídico atual, de acordo com ele, que o juspositivismo se mostra insuficiente para resolver os conflitos jurídicos.

${ }^{75}$ FREITAS FILHO, Roberto. A crise do Direito e Juspositivismo: a exaustão de um paradigma. 2013. 123 f. Dissertação (Mestrado em Direito) - Faculdade de Direito, Universidade de São Paulo. 2013.

${ }^{76}$ Explicado no capítulo Crítica a linguagem jurídica: a fronteira entre a ciência do direito e o Discurso Científico.

77 JUNIOR, Ronaldo Porto Macedo.; BARBIERI, Catarina Helena Cortada. Direito e interpretação: racionalidades e instituições, São Paulo: Saraiva, 2011, p.363-380.
} 
fundamentação consistente. Nesse sentido, Habermas aponta uma pertinente crítica que é claramente colocada por Porto Macedo:

"O sopesamento, além de irracional, implica um enorme risco para a garantia dos direitos fundamentais, que perde o seu caráter vinculante. Segundo ele (Habermas), os direitos fundamentais perdem o seu caráter deontológico e passariam a ter um caráter sobretudo axiológico e teleológico. As normas deixam de veicular o que deve ser, e passariam a ser um material para se decidir o que é bom ou o que é ruim." 78

Diante desse problema, qual é saliente na contemporaneidade é fundamental a necessidade de buscar uma forma de controle que preze, a medida do possível, objetividade para assim coadunar numa racionalidade jurídica. Todavia, a totalidade objetiva no âmbito jurídico, evidentemente, é impossível. ${ }^{79} \mathrm{Nem}$ por isso, não existe vias razoáveis para se pensar formas objetivas de controle na margem para o uso da ponderação. De certo, pode-se cogitar uma alternativa possível para tanto: o controle intersubjetivo. ${ }^{80}$

A primeiro momento, é necessário repensar a natureza da objetividade da qual está-se a falar. Apesar de estar usualmente relacionada às ciências da natureza ou a lógica. A objetividade não se resume a fórmulas. Pode-se pensar, dentre outros sentidos, na objetividade dialogal entre partícipes dos quais colaboram nas decisões. A explicitação de pontos de partida de argumento para fundamentação nas decisões já conferem essa qualidade que busca-se para racionalidade jurídica. O diálogo, com efeito, funciona como uma plataforma para a objetividade social. Dessa mediação inter-argumentativa, emerge o controle social que também é, a saber, coletivo, na medida em que uma proposição jurídica é fiscalizada por instituições, por comunidades políticas e pela academia.

O juiz, nessas instâncias, passa a não decidir de forma autônoma levado pela própria subjetivação e independente consciência. O limite da esfera judiciária, por vezes, pode ser entendida enquanto a sustentação da racionalidade jurídica se forma por uma objetividade social. Neste sentido também a forma pela qual é aplicada a ponderação proporciona um novo paradigma jurídico em que o fundamento do Direito é construído nem por meios formais como no positivismo

\footnotetext{
78 JUNIOR, Ronaldo Porto Macedo.; BARBIERI, Catarina Helena Cortada. Direito e interpretação: racionalidades e instituições, São Paulo: Saraiva, 2011, p.363-380.

79 Ibidem.

80 lbidem.
} 
jurídico, nem por meios materiais como no jusnaturalismo, mas por meios procedimentais.

"O direito ganha, assim, uma dimensão moral que não significa a crença numa ordem natural, mas sim a ideia de que a legitimidade do ordenamento jurídico depende do procedimento de sua produção e aplicação, que deve ser democrático e racionalizado"81.

Nesse raciocínio, mesmo que de forma tênue, é manifesta uma possível justificação e controle para aplicação da ponderação, o qual, no entanto, não expressa racionalidade jurídica própria, mas por com vínculos exteriores. Por isso, é mister frisar que o discurso jurídico não pretende sustentar que uma determinada proposição seja mais racional do que outra, visto que é sustentada, na maioria das vezes, por questões de preferência de valores. ${ }^{82}$. É necessário, nesse ínterim, uma inspeção intersubjetiva das proposições.

Pode-se concluir, portanto, o porquê do Direito ser contraditório. De certo, a partir de expressões do saber jurídico de relevância paradigmática com propósitos racionais porém que, em última instância, não tem essa roupagem ou não se sustentam independentemente como método. Contraditória, nesse sentido, pois ao estar imerso em uma realidade dialética, o entendimento que se tem por verdade é colocado ao intercâmbio do tempo e espaço e a necessidade de ser compreendida em sua totalidade.

Resta agora analisar depois de identificar as mudanças no Direito, a questão da legitimidade da decisão judicial que se mostra sob severas críticas na contemporaneidade em função da judicialização da política.

\subsection{Legitimidade de uma decisão judicial: racionalidade procedimental institucionalizada juridicamente}

Discutiu-se ao longo da pesquisa, questões que concernem a racionalidade do Direito. Nesta última parte teórica será dedicado a estudar as formas de legitimidade das decisões judiciais visto sua extensão de competência para dar efetividade na democratização do Direito. Viu-se a partir desta pesquisa, que no

${ }^{81}$ CARVALHO, Juliana Brina Corrêa Lima de. Sobre os Limites da Argumentação Jurídica. Revista de Direito Brasileira, [S.I.], v. 2, n. 2, p. 47-94, oct. 2012. ISSN 2358-1352. Disponível em: <http://www.rdb.org.br/ojs/index.php/rdb/article/view/73>. Acesso em: 12 Aug. 2017. doi:10.5585/73.

82 Ibidem. p. 60. 
positivismo jurídico, a legitimidade é alcançada pela legalidade, qual é fruto de um processo legislativo, portanto de ordem política. Tal premissa tornou possível o ofício jurídico desvinculado da política, visto o poder jurídico ser instituído pela política. No entanto, em função da complexidade do Direito, em virtude, sobretudo da mudança de um Estado Liberal para um Estado interventor, social e previdenciário, tornou-se questionável a legitimidade do Direito única e exclusivamente através da legalidade ${ }^{83}$.

"Não é surpreendente, portanto, que o direito ao acesso efetivo à justiça tenha ganho particular atenção na medida em que as reformas do welfare state têm procurado armar os indivíduos de novos direitos substantivos em sua qualidade de consumidores, locatários, empregados e, mesmo, cidadãos. De fato, o direito ao acesso efetivo tem sido progressivamente reconhecido como sendo de importância capital entre os novos direitos individuais e sociais, uma vez que a titularidade de direitos é destituída de sentido, na ausência de mecanismos para sua efetiva reivindicação." 84

Essa mudança que está se evidenciando cada vez mais na contemporaneidade ocorre em função da atividade jurídica desempenhar o trabalho de tutelar os direitos fundamentais. A condição austera do Estado, limitado somente a proteção dos cidadãos ao aparelho estatal se manifesta insuficiente, uma vez que as demandas sociais, em virtude da complexidade da sociedade, exige do Estado uma maior participação na vida do cidadão.

Para coadunar com a guinada intersubjetiva de construção do conhecimento e da verdade como foi exposto na pesquisa. Percebe-se que a legitimidade das decisões judiciais deve ser feita a partir de procedimentos democráticos. Neste sentido Servilha Monteiro aduz:

"Impulsionados pelo Estado social, a manutenção não só do Estado de Direito, mas do Estado Democrático de Direito, levam à idéia de autoorganização da comunidade jurídica, e, portanto, a Constituição não pode ser mais entendida como uma ordem que regula a relação entre o Estado e os cidadãos. [...] Ao contrário, a Constituição determina procedimentos políticos segundo os quais, cidadãos, assumindo seu direito de autodeterminação, podem perseguir cooperativamente o projeto de produzir condições justas de vida. Somente as condições processuais da gênese democrática das leis asseguram a legitimidade

${ }^{83}$ MAILLART, A.; RIOS, B. O alcance do acesso à justiça eficiente por intermédio do ativismo judicial. Pensar - Revista de Ciências Humanas e Jurídicas, Fortaleza, v. 21, n.1, p. 9-39, 2016.

${ }^{84}$ CAPPELLETTI, Mauro; GARTH, Bryant. Acesso à justiça. Trad. Ellen Gracie Northfleet. Porto Alegre: Fabris, 1988, p. 11. 
do Direito"85.

Nessas instâncias, a noção de Estado de Direito sobressai aquela concepção restrita ao legalismo para atuação do Estado como agente que promove a justiça. Se trata, portanto, ligeiramente, de uma transição de primazia de questões substanciais a questões formais. Tais fatos são consequências de Constituições que proporcionam direitos sociais em maior quantidade em forma de direitos positivos.

Problemas, todavia, são frequentes quando o judiciário toma medidas que, ordinariamente, não competem a ele, já que todo entendimento do Estado Liberal não organizou as funções dessa forma. Uma delas seria o Direito suprapositivo que suspende a divisão entre normatização e aplicação, fazendo da atividade jurídica concorrente a legislação. Normas indeterminadas, quais são os princípios são o invólucro principal dessas críticas. Portanto, o eixo divergente a tomada de decisões político-jurídico, se daria no âmbito delas serem antidemocráticas, por não serem decisões representativas.

De fato, está a surgir um novo marco jurídico com a inserção da moral nas esferas constitutivas do Direito. ${ }^{86}$ Efetivamente, pode-se perceber tal atribuição quando, necessariamente, na vontade do legislador é evidente nos discursos políticos fundamentações morais que engrenam o controle jurídico de normas. Torna-se claro, logo, que no processo legislativo, a moralidade é introduzida no direito positivo.

Portanto, "a legitimidade deve, sempre, a um poder político, exercida nas formas de um direito positivo, cativo de fundamentação, um conteúdo moral implícito das qualidades formais do Direito". ${ }^{87}$ A legitimidade não só se manifesta, unilateralmente, num campo jurisdicional (Direito) e, do outro lado, da legislação política. Mas pelo procedimento do qual uma norma é formada. A opinião pública interage com a esfera jurídica na medida em que normas ordinárias e princípios carregam valorações e moralidade na sua substância.

A moralidade que se defronta no Direito, portanto, é de natureza processual. Atuante na razão prática e no seu ofício de justiça. A legalidade pode gerar

\footnotetext{
${ }^{85}$ MONTEIRO, Cláudia Servilha. Racionalidade nas decisões judiciais políticas. Revista Brasileira de estudos políticos, Belo Horizonte, v. 96, n. 114, p. 219-262, 2007.

${ }^{86}$ HABERMAS, Jurgen. Direito e Democracia: entre facticidade e validade. Rio de Janeiro: Tempo Brasileiro, 1997.

${ }^{87}$ HABERMAS, Jurgen. Direito e Moral. Lisboa:Instituto Piaget, 1992.
} 
legitimidade quando "procedimentos jurídicos de decisão, que facultam os discursos morais, são institucionalizados" tais como a regra maioritária, de ordem parlamentar, direito de sufrágio, formação de opinião são manifestas.

"Acredita-se que os critérios de legitimidade e validade do Direito hoje estão diretamente relacionados com o processo de criação do próprio Direito (Law Making) que não se resume a ordem normativa hierarquizada e, em igual medida, não se limita a uma dogmática normativa hermética. [...] Sobretudo no processo de criação do Direito enquanto fenômeno social complexo [...] e também na regra do reconhecimento (enforcement) estão os critérios legítimos e válidos de formação do Direito."88

Por estas razões, pode-se perceber os minuciosos, porém, consistentes pensamentos qual tornam possível uma legitimação jurídica que intervém no âmbito político. O processo percorrido pela formação do argumento de razão democrática é uma possível alternativa para tanto que é construída através da percepção das demandas sociais. Neste sentido, o que é evidente nos argumentos tal qual tentam colocar esse tipo de raciocínio procedimental em pauta, partem de uma primazia da racionalidade substancial à racionalidade formal. Característica, portanto, que aos poucos é cada vez mais presente na esfera jurídica.

\subsection{Racionalidade jurídica no campo do agir decisional: uma análise dos votos do Supremo Tribunal Federal}

$\mathrm{Na}$ primeira parte da pesquisa, dedicou-se na investigação em torno do desenvolvimento da racionalidade jurídica. Observou-se uma possível emergência racional de uma nova natureza em função da necessidade política para legitimar seu argumento. A análise de ordem teórica feita até agora tem como uma orientação uma razão prática. Isto é, a partir da fundamentação epistemológica procura-se, nessa seguinte etapa, buscar as razões que são evidentes empiricamente pelo voto dos ministros. Razão prática, nesse sentido, é argumento fundamentado e institucionalizado.

Portanto, nesta segunda parte, com o subsídio teórico construído até aqui, será dado sequência a uma análise dos votos dos ministros do Supremo Tribunal Federal. Dando atenção, prioritariamente, ao objeto de estudo evocado a partir da seguinte pergunta: Que tipo de racionalidade jurídica é exposta no voto para

${ }^{88}$ CHEVITARESE, Alessia Barroso Lima Brito Campos. O império da lei a lei do Império: quem governa o direito?. Revista de Direito Internacional, Brasília, v. 9, n. 4, p. 249-265, 2012. 
justificar o argumento? Por conseguinte, delimitaremos em qual categoria racional o argumento pertence para, finalmente, por uma investigação justa ao intercâmbio do espaço e tempo, analisar sua consistência jurídica.

Cabe informar que a seleção dos votos foram feitas com o intuito de distinguir com mais rigor a diferença argumentativa com a qual cada tipo racional transparece na sua forma mais clara e distinta. Portanto, focamos numa abordagem que tangencia um momento pré-constituição de 1988 e pós-constituição de 1988, visto que assim adequaria ao que almeja-se.

A metodologia, com efeito, não se difere do que fez-se até agora. Por isso, é historicista, ou seja, será investigado as razões práticas levando em consideração a situação política e jurídica do seu devido tempo. Simultaneamente, será analisado possíveis espectros tênues, mas salientes que se tornam evidentes entre conflitos de paradigmas. A racionalidade jurídica de um voto se manifesta, logo, numa conjugação das exigências sociais e orientação teórica de novas epistemologias jurídicas.

\subsubsection{Primeiro caso: Mandado de Segurança n 20. 257 - Distrito Federal}

O primeiro caso aqui exposto trata de um Mandado de segurança, MS 20.257/DF, relator para o caso, Min. Décio Mirante e relator para o Acórdão Min. Moreira Alves, julgado pelo Pleno em 08.10.1980. Referido MS foi impetrado contra ato da Mesa do Congresso Nacional que admitiu a deliberação de proposta de emenda constitucional, que os impetrantes alegavam ser tendente à abolição da República. No caso em tela, Será analisado o voto do relator, ministro Décio Miranda que ocorreu em oito de outubro de 1980. A argumentação do ministro é baseada essencialmente nesse trecho "Não sendo liminarmente (na sessão de recebimento) rejeitada pelo Presidente do Congresso a proposta de Emenda, não cogita o dito Regimento Comum de outro momento em que possa, por ele ou pela Mesa a que preside, ser rejeitada". De acordo com a perspectiva do autor do voto, não é possível fazer uma intervenção de controle constitucional, uma vez que o período para tal ofício já foi passado do previsto. Portanto, de acordo com ele "a pretensão de fazer com que sobre ela não haja deliberação só se pode dirigir contra o próprio Congresso Nacional, não mais contra a Mesa do Congresso"

Observa-se, claramente, um rigor ao atendimento processual mesmo que haja um atrito material presente. Por essas características, é evidente uma postura 
juspositivista. Todavia, não observamos no voto do ministro, um modo de fundamentação e aplicação da lei ao que diz respeito a uma doutrina que segue os aspectos hermenêuticos de uma visão voluntarista. Deliberou-se na conformidade entre a vontade do legislador e a vontade da lei.

Analisando de forma rigorosa, é ausente no voto do ministro uma autonomia, isto é, uma discricionariedade que corrobora numa decisão judicial fluida a operações intelectivas do juiz. Podemos ver, por excelência, a execução de um positivismo legalista e uma espécie de "ideologia da codificação". Trata-se de uma decisão que está em conformidade com seu contexto histórico em que é caracterizado pelo fetichismo da norma. ${ }^{89}$ Mecanismo jurídico esclarecido no trecho de Bastos Santos "Diante da supervalorização da lei o aplicador do direito deve apenas identificar a norma aplicável e subsumir a ela o fato concreto, através da subsunção." 90 . O sistema jurídico, nessas instâncias, é completo e coerente.

Tal forma de interpretação exegética não condiz com a interpretação de Kelsen por este ter confluências com a Escola do Direito Livre, uma instituição oposta à aplicação da literalidade da lei. É errôneo entender que o jurista de Viena procura criar um sistema jurídico que não sofre influências exteriores e possui em sua totalidade uma aplicação independente a outras faculdades e disciplinas. Razão pela qual percebemos que a orientação hermenêutica desse autor, como resultado de uma decisão judicial, em última instância, é discricionária e, portanto, política. Com efeito, o modo de aplicação das normas de Kelsen não segue inteiramente um positivismo jurídico clássico. Seu esforço é voltado a um modelo auto-referencial dentro de uma teoria pura do Direito e não uma teoria do Direito puro. "Mediante a interpretação teórica não se pode tomar decisões sobre as possíveis significações desvendadas; estas são competências dos órgãos encarregados de aplicar o direito. Decidir sobre os sentidos que devem ser adjudicados a uma norma é tarefa da Política Jurídica"91. O entendimento da distinção entre uma política jurídica e uma teoria política elimina uma possível estigmatização do positivismo jurídico e deixa claro que tipo positivismo está sendo investigado.

89 NETO. Arnaldo Bastos Santos. A questão da justiça de Kelsen a Luhmann: do abandono à recuperação. 2010. 324 f. Tese (Doutorado em Direito) - Universidade do Vale do Rio dos Sinos Ciências Jurídicas, São Leopoldo, 2010.

90 Ibidem. p. 67.

${ }^{91}$ WARAT, Luis Roberto. A pureza do Poder. Florianópolis: Editora da UFSC, 1983, p. 29. 


\subsubsection{Segundo caso: Ação Direta de Inconstitucionalidade no 3510 - Distrito Federal}

A ADI 3510 foi uma ação de relatoria do Min. Ayres Britto, julgada pelo Pleno em 29.05.2008. Trata-se de um inegável caso em que se discutiu questões dos quais não possuem uma resposta correta, por estarem num âmbito moral e religioso, uma vez que a ADI 3510, tratou da biossegurança. Versando sobre questões de utilização de células-tronco embrionários para fins de pesquisa, o caso tangência problemas como a busca para possíveis definições de vida e proteção aos abusos tecnocientíficos. Inúmeras aporias são evidentes para tais temas dos quais possivelmente nenhuma forma de consenso na esfera pública será manifesta. Porém, no âmbito jurídico é necessário que tome-se uma decisão. Nessa ambivalência que transcende respostas que oscilam entre o certo e o errado, o voto do Ministro Gilmar Mendes procurou por uma possível solução para decisão, tal qual permeia no sentido democrático e, portanto, principiológica.

Ao longo do voto, o ministro trata de deixar evidente a falta de legislação específica ao tema mesmo visto ser assunto de extrema importância. Numa comparação do Direito brasileiro com Direito estrangeiro, Gilmar Mendes delineia o quão longínquo está a situação do Brasil em relação a outros países no que concerne o ordenamento jurídico. Para sanar este abismo que se cria entre a falta de legislação específica e direitos a serem protegidos, o ministro evoca pensamentos de raízes principiológicas. De certo, a partir do princípio de responsabilidade fundamenta seu discurso numa nova ética para lidar com os desenvolvimentos técnicos.

"O princípio responsabilidade - ensina Hans Jonas - contrapõe a tarefa mais modesta que obriga ao temor e ao respeito: conservar incólume para o homem, na persistente dubiedade de sua liberdade que nenhuma mudança das circunstâncias poderá suprimir, seu mundo e sua essência contra os abusos de seu poder"92.

Além disso, o engajamento jurídico do ministro também se volta pelo método que interpreta as insuficiências legislativas. A preocupação que é evidente no voto sobre questões de hermenêutica aponta para um déficit na racionalidade jurídica proveniente do positivismo jurídico.

\footnotetext{
92 JONAS, Hans. O princípio responsabilidade. Ensaio de uma ética para a civilização tecnológica. Trad. Marijane Lisboa, Luis Barros Montez. Rio de Janeiro: Contraponto; 2006, p. 23.
} 
"Segundo a jurisprudência do Supremo Tribunal Federal, porém, a interpretação conforme à Constituição conhece limites. Eles resultam tanto da expressão literal da lei quanto da chamada vontade do legislador. A interpretação conforme à Constituição é, por isso, apenas admissível se não configurar violência contra a expressão literal do texto e não alterar o significado do texto normativo, com mudança radical da própria concepção original do legislador"93.

Lembra-se que no que concerne a interpretação, o positivismo jurídico se debruçou pouco. Resumindo-se, a grosso modo, ao convencionalismo. O póspositivismo que tratou de flexibilizar a forma pela qual a aplicação das normas eram feitas. A racionalidade jurídica fundamentada a partir do argumento de Gilmar Mendes se desenvolve numa razão menos rígida e menos formalizada com o intuito de dinamizar do Direito e encontrar uma alternativa razoável para decisão judicial.

Trata-se, nesse sentido, de tentar visualizar possíveis alternativas ao que diz respeito a casos difíceis, os quais não possuem precedentes e jurisprudências anteriores para segurança jurídica e normas para tanto. Nesses casos, como o ministro fez, é necessário procurar sanar tais problemas por vias principiológicas e hermenêuticas. De certo, é evidente ao analisar o voto do ministro. Há no argumento, logo, pensamentos pós-positivistas visando atenuar a discricionariedade, atender a uma comunidade personificada e protagonizar a justiça.

\subsubsection{Terceiro caso Ação Direta de Inconstitucionalidade (ADI) 4277 e a Arguição de Descumprimento de Preceito Fundamental (ADPF) 132 - Rio de Janeiro.}

O terceiro e último caso a ser analisado tem como tema a União Homoafetiva, julgado pelo Supremo em 05.05.2011. De inicial, foi selecionado o voto relator do ministro Ayres Britto, porque ao longo da investigação, percebeu-se um engajamento no sentido moral e civil. Características das quais no Direito contemporâneo, cada vez mais se mostram evidentes na fundamentação de um argumento. O assunto é interessante, pois deixa saliente mudanças de valores no que dizem respeito a união entre pessoas conquanto foi reconhecido até então. Além disso, o voto do ministro deixa explícito as alterações morais ligado a necessidade de mudanças jurídicas, e de quanto há um reducionismo e um espírito

93 ADIn 2405-RS, Rel. Min. Carlos Britto, DJ 17.02.2006; ADIn 1344-ES, Rel. Min. Joaquim Barbosa, DJ 19.04.2006; RP 1417-DF, Rel. Min. Moreira Alves, DJ 15.04.1988; ADIn 3046SP, Rel. Min. Sepúlveda Pertence, DJ 28.05.2004. 
conservador na esfera jurídica. O que acaba, por fim, estagnando os avanços jurídicos.

As exigências sobre Poder Judiciário quais deveriam tutelar os Direitos, em última instância, tomado por uma complacência e rigidez jurisprudencial, não respeita o princípio da igualdade, visto que pessoas do mesmo sexo não conseguem ter acesso ao casamento. Direito que, no entanto, universalmente, deveria ser dado a todos. Portanto, são problemas jurídicos em que a interpretação deve ser repensada. O autor do voto, ciente dessa questão, propõe que seja feita uma leitura conforme a Constituição. Isso significa, em outras palavras, interpretá-la confluente ao significado do tempo. Para tanto, requer que o hermeneuta conheça a sua época, que seja contemporâneo. Sobre isso Agamben discorre:

"A contemporaneidade, portanto, é uma singular relação com o próprio tempo que adere a este e, ao mesmo tempo, dele toma distâncias; mais precisamente é essa a relação com o tempo que a este adere através de uma dissociação e um anacronismo. Aqueles que coincidem muito com a época, que em todos os aspectos a esta aderem perfeitamente, não são contemporâneos porque, exatamente por isso, não conseguem vê-la, não podem manter fixo o olhar sobre ela."94

Trata-se, portanto, de tomar uma decisão em que a percepção do tempo não pode ser privado a hodiernidade, mas a partir de um dinamismo histórico. Com olhos alheios ao próprio tempo, mas pertencendo a ele, o juiz expande seu escopo jurisdicional e cria condições para se decidir melhor. É o que se observa ao ler o voto do ministro. Sua interpretação segue uma racionalidade jurídica confluente às exigências sociais. Assim, cria-se, de forma direta ou indireta, um diálogo entre a Corte Constitucional e o povo, acabando por fornecer um caráter democrático para decisão.

As decisões judiciais vinculadas a uma dada natureza racional criam argumentos dos quais tentam justificar suas proposições. Esse voto expressa evidentemente esse tipo de inclinação, qual seja, de fundamento democrático. Como vimos a partir da abordagem teórica da pesquisa, ela se legitima através do processualismo moral e, neste caso, por uma tênue razão comunicativa. Nesse sentido, também tem um aspecto pós-positivo. Flexibilidade jurídica que no século XX, difícil de ser observada.

${ }^{94}$ AGAMBEN. Giorgio. O que é contemporâneo e outros ensaios. Chapecó: Unochapecó, 2009. 


\section{Conclusão}

É evidente aqui, uma divergência conceitual do Direito, em que está em jogo sua natureza jurídica. Por isso, a reflexão que foi feita ao longo da pesquisa, caminha na explicitação do ponto teórico tal qual fundamenta o Direito enquanto razão prática.

Como dito ao longo da pesquisa, baseou-se no pensamento dialético para investigação dos paradigmas jurídicos. Desta feita, observou-se rupturas sobre quais um pensamento hegemônico jurídico se torna insuficiente para assim, sobrepor ou reconciliar, por vezes de maneira tênue ou radical, uma nova forma de se pensar o Direito.

Como características acentuadas foi observado a natureza do conhecimento jurídico sendo contingente e contraditório, o que levou a concluir que a tendência epistemológica jurídica caminha para construções intersubjetivas do conhecimento. Com efeito, a racionalidade jurídica toma roupagens democráticas, de efeitos consensuais e sociais, uma vez que é edificada por uma razão comunicativa. $\mathrm{O}$ sentido da verdade, nessas instâncias, também confluente a racionalidade jurídica, se transforma. É, por isso, que é não preferível de se pensar, visto correr riscos de anacronismo e estagnação do conhecimento, numa semântica de verdade estática. Sob influência do intercâmbio de espaço e tempo, tem-se a necessidade de mudar as orientações teóricas, sobretudo as de razão prática, para se adequar às demandas do respectivo contexto histórico.

Pôde-se observar, logo, que o Direito retém, na sua mais íntima essência, uma leveza. Característica do qual pode ser levado em sentido positivo e negativo. Esta pesquisa, no entanto, a partir das análises feitas, percebe que tal aspecto é enriquecedor e pelo fato da ciência do Direito compor, em certa medida, conceitos fluidos, resguarda toda a possibilidade de se adaptar a mudanças que surgem na sociedade.

Conclui-se, por fim, que a razão da racionalidade jurídica não habita em uma espécie de tipo ideal. Ela é construída mediante a comparação de discursos jurídicos em que o melhor argumento será a vinculante de verdade na esfera pública e jurídica. Racionalidade jurídica e, com efeito, uma decisão judicial, comportam esse mecanismo líquido, qual dá ideia de movimento e constante mudança perante a realidade. 


\section{Referências}

AGAMBEN. Giorgio. O que é contemporâneo e outros ensaios. Chapecó: Unochapecó, 2009.

BACON, Francis. Novo Organon. São Paulo: Edipro, 2014.

CHEVITARESE, Alessia Barroso Lima Brito Campos. Controle jurisdicional do processo legislativo. Curitiba: Juruá, 2016.

CHEVITARESE, Alessia Barroso Lima Brito Campos. O império da lei a lei do Império: quem governa o direito?. Revista de Direito Internacional, Brasília, v. 9, n. 4, p. 249-265, 2012.

NETO. Arnaldo Bastos Santos Neto. A questão da justiça de Kelsen a Luhmann: do abandono à recuperação. 2010. 324 f. Tese (Doutorado em Direito) - Universidade do Vale do Rio dos Sinos Ciências Jurídicas, São Leopoldo, 2010.

BAUMAN, Zygmunt. Modernidade líquida. Rio de Janeiro: ZAHAR, 2001.

BOBBIO, Norberto. O positivismo jurídico. São Paulo: Ícone Editora Ltda, 1999.

BODIN, Jean. On Sovereignty. Cambridgeshire: Cambridge UK, 1992.

CAPPElletTI, Mauro; GARTH, Bryant. Acesso à justiça. Porto Alegre: Fabris, 1988, p. 11.

CARVALHO, Juliana Brina Corrêa Lima de. Sobre os Limites da Argumentação Jurídica. Revista de Direito Brasileira, [S.I.], v. 2, n. 2, p. 47-94, oct. 2012. ISSN 2358-1352. Disponível em: <http://www.rdb.org.br/ojs/index.php/rdb/article/view/73>. Acesso em: 12 Aug. 2017. doi:10.5585/73.

CASTRO COURA, A.;TAUFNER ZANOTTI, B .(Pós)Positivismo jurídico e a Teoria do Direito como integridade de Ronald Dworkin. Nomos, Fortaleza, v. 34, n. 2, p. 58, 2014.

DESCARTES, René. Meditações Metafísicas. São Paulo: Edipro, 2016.

DESCARTES, René. O Discurso sobre Método. Rio de Janeiro: Vozes, 2017.

DWORKIN, Ronald. O império do direito. São Paulo: Martins Fontes, 2007, p. 10.

FARIA, José Eduardo. A crise do Direito numa Sociedade de Mudanças. Brasília: Editora UNB, 1988.

FARIA, José Eduardo. O direito na economia globalizada. São Paulo, Malheiros, 1999.

FARIA, José Eduardo. O direito na economia globalizada. São Paulo, Malheiros, 1999. BOBBIO, Norberto. O positivismo jurídico. São Paulo: Ícone Editora Ltda, 1999. 
FREIRE, Paulo. Pedagogia do Oprimido. Rio de Janeiro: Paz e Terra Ltda, 2014. FERRAZ JUNIOR, Tércio Sampaio. Introdução ao estudo do Direito. São Paulo: Atlas, 2003.

FREITAS FILHO, Roberto. A crise do Direito e Juspositivismo: a exaustão de um paradigma. 2013. 123 f. Dissertação (Mestrado em Direito) - Faculdade de Direito, Universidade de São Paulo. 2013.

GOMES, Roberto. Crítica da razão Tupiniquim. São Paulo: FTD, 1990.

GOYARD-FABRE, Simone. Os fundamentos da ordem jurídica. São Paulo: Martins Fontes, 2007.

GRAÇA NETO, Antônio. Kelsen e Wittgenstein: as interfaces da lógica. Seqüência: Estudos Jurídicos e Políticos, Florianópolis, p. 115-123, jan. 1996.

GODOY, Arnaldo Sampaio de Moraes. O realismo jurídico em Oliver Wendell Holmes Jr. Disponível em: http://www2.senado.leg.br/bdsf/bitstream/handle/id/92825/Godoy\%20Arnaldo.pdf. Data de acesso: 04 de agosto de 2017.

HABERMAS, Jurgen. Direito e Democracia: entre facticidade e validade. Rio de Janeiro: Tempo Brasileiro, 1997.

HABERMAS, Jurgen. Direito e Moral. Lisboa:Instituto Piaget, 1992.

HABERMAS, Jurgen. Teoria e práxis. São Paulo: UNESP, 2011.

HESPANHA, Antônio Manuel . História das instituições; época medieval e moderna. Coimbra: Livraria Almedina, 1982.

HOBBES, Thomas. Leviatã ou matéria, forma e poder de uma república eclesiástica e civil. São Paulo: Martins Fontes, 2014.

HOLMES, Oliver Wendell. The Common Law. Minnesota: GALE M. M. LAW, 2010.

Immanuel Kant. Resposta à pergunta: O que é o esclarecimento. Disponível em:https://bioetica.catedraunesco.unb.br/wp-content/uploads/2016/04/Immanuel-

Kant.-O-que-\%C3\%A9-esclarecimento.pdf . Acesso em: 25 de julho de 2017.

JONAS, Hans. O princípio responsabilidade. Ensaio de uma ética para a civilização tecnológica. Rio de Janeiro: Contraponto, 2006, p. 23.

KANT, Immanuel. Crítica da razão Pura. Rio de Janeiro: Vozes, 2012.

KELSEN, Hans. Teoria Pura do Direito. Coimbra: Armênio Amado, 1976.

KELSEN, Hans. Teoria Pura do Direito. São Paulo: WMF Martins Fontes, 2011.

KONDER, Leandro. O que é dialética. São Paulo: Brasiliense, 1981.

KUHN, Thomas. Estruturas das revoluções científicas. São Paulo: Perspectiva, 
2010.

MACEDO JUNIOR, Ronaldo Porto. O decisionismo jurídico de Carl Schmitt. Lua Nova, São Paulo, n. 32, p. 201 - 241, Apr. 1994.

MACEDO JUNIOR, Ronaldo Porto; BARBIERI, Catarina Helena Cortada. Direito e interpretação: racionalidades e instituições, São Paulo: Saraiva, 2011, p.363-380.

MAILLART, A.; CARLOS RIOS, B. O alcance do acesso à justiça eficiente por intermédio do ativismo judicial. Pensar - Revista de Ciências Humanas e Jurídicas, Fortaleza, v. 21, n.1, p. 9-39, 2016.

MARX, Karl. Ideologia alemã. São Paulo: Boitempo, 2007.

MARYIOLI, Aglaé. Billier, Jean Cassien. História da Filosofia do Direito. São Paulo: Manole Ltda, 2005.

MCCAULEY LANDIS. James. The Business of the Supreme Court: A Study in the Federal Judicial System. Abingdon on Thames: Routledge, 2006.

MONTEIRO, Cláudia Servilha. Racionalidade nas decisões judiciais políticas. Revista Brasileira de estudos políticos, Belo Horizonte, v. 96, n. 114, p. 219-262, 2007.

MONTESQUIEU, Charles. O espírito das leis. São Paulo: Martins Editora, 2005.

PEREIRA, Caio Mário da Silva. Instituições do direito civil. Rio de Janeiro: Forense, 2016.

POPPER, Karl. A lógica da pesquisa científica. São Paulo: Cultrix, 2013.

RODRÍGUEZ, Víctor Gabriel. Argumentação jurídica. São Paulo: WMF Martins Fontes, 2015.

ROUSSEAU, Jean Jacques. Discurso sobre a origem e os fundamentos sobre a desigualdade entre os homens. São Paulo: Edipro, 2015.

ROUSSEAU, Jean Jacques. Do contrato social. Rio de Janeiro: Vozes, 2017.

SCHMITT, Carl. Les trois types de pensée juridique. Paris: Quadrige, 2015.

SEELAENDER, Airton. A "polícia" e as funções do Estado - notas sobre a polícia do Antigo regime. Revista da Faculdade de Direito - UFPR, Curitiba, n.49, p-73-87, 2009.

SEELAENDER, Airton. O contexto do texto: notas introdutórias à história do direito público na idade moderna. Revista Seqüência, no 55, p. 253-286, dez. 2007.

STIELTJES, Claudio. Jurgen Habermas: a desconstrução de uma teoria. São Paulo: Germinal, 2001.

STRECK, Lenio L. O que é isto? Decido conforme minha consciência. Porto Alegre: 
Livraria do Advogado, 2012.

STRECK, Lenio L. Hermenêutica Jurídica $e(m)$ Crise. Porto Alegre: Livraria do Advogado, 1999.

VASCONCELOS, Arnaldo. Teoria Pura do Direito: repasse crítico de seus principais fundamentos. Rio de Janeiro: GZ Ed, 2010.

VASCONCELOS, Arnaldo. Teoria da Norma Jurídica. São Paulo: Malheiros, 2006.

VASCONCELOS, Arnaldo. Teoria da Norma Jurídica. São Paulo: Malheiros, 2006.

WARAT, Luis Roberto. A pureza do Poder. Florianópolis: Editora da UFSC, 1983.

WEBER, Max. Ética protestante e o espírito do capitalismo. São Paulo: Companhia das letras, 2014.

WITTGENSTEIN, Ludwig. Tractatus-Lógico- Philosophicus. São Paulo: EDUSP, 2001. 